\title{
Allergic Inflammation Leads to Neuropathic Pain via Glial Cell Activation
}

\author{
Ryo Yamasaki, ${ }^{1}$ Takayuki Fujii, ${ }^{1}$ Bing Wang, ${ }^{1}$ Katsuhisa Masaki, ${ }^{1}$ Mizuho A. Kido, ${ }^{2}$ Mari Yoshida, ${ }^{3}$ Takuya Matsushita, ${ }^{1}$ \\ and Jun-ichi Kira ${ }^{1}$ \\ ${ }^{1}$ Departments of Neurology and Neurological Therapeutics, Graduate School of Medical Sciences, Kyushu University, Fukuoka, Japan 812-8582, \\ ${ }^{2}$ Department of Molecular Cell Biology and Oral Anatomy, Graduate School of Dental Sciences, Kyushu University, Fukuoka, Japan 812-8582, \\ and ${ }^{3}$ Department of Neuropathology, Institute for Medical Science of Aging, Aichi Medical University, Aichi, Japan 480-1195
}

Allergic and atopic disorders have increased over the past few decades and have been associated with neuropsychiatric conditions, such as autism spectrum disorder and asthmatic amyotrophy. Myelitis presenting with neuropathic pain can occur in patients with atopic disorder; however, the relationship between allergic inflammation and neuropathic pain, and the underlying mechanism, remains to be established. We studied whether allergic inflammation affects the spinal nociceptive system. We found that mice with asthma, atopic dermatitis, or atopic diathesis had widespread and significantly more activated microglia and astroglia in the spinal cord than those without atopy, and displayed tactile allodynia. Microarray analysis of isolated microglia revealed a dysregulated phenotype showing upregulation of M1 macrophage markers and downregulation of M2 markers in atopic mice. Among the cell surface protein genes, endothelin receptor type B $(E D N R B)$ was most upregulated. Immunohistochemical analysis revealed that EDNRB expression was enhanced in microglia and astroglia, whereas endothelin-1, an EDNRB ligand, was increased in serum, lungs, and epidermis of atopic mice. No EDNRA expression was found in the spinal cord. Expression of FBJ murine osteosarcoma viral oncogene homolog B was significantly higher in the dorsal horn neurons of asthma mice than nonatopic mice. The EDNRB antagonist BQ788 abolished glial and neural activation and allodynia. We found increased serum endothelin-1 in atopic patients with myelitis and neuropathic pain, and activation of spinal microglia and astroglia with EDNRB upregulation in an autopsied case. These results suggest that allergic inflammation induces diffuse glial activation, influencing the nociceptive system via the EDNRB pathway.

Key words: allergy; astroglia; EDNRB; microglia; neuropathic pain

\section{Significance Statement}

The prevalence of allergic disorders has markedly increased over the past few decades. Allergic disorders are associated with neuropsychiatric conditions; however, the relationship between allergic inflammation and CNS complications is unknown. A peculiar myelitis presenting with persistent neuropathic pain has been reported in patients with allergic disorders. We studied how atopy exerts substantial influence on the nociceptive system. We found that mice with allergic disorders had severe allodynia with activated astroglia and microglia, and showed marked upregulation of endothelin-1 (ET-1) receptor type B (EDNRB) in the spinal cord. A selective EDNRB antagonist prevented allodynia and glial activation. Our findings suggest a novel mechanism whereby atopy induces glial activation and neuropathic pain via an ET-1/EDNRB pathway.

\section{Introduction}

The worldwide prevalence of allergic and atopic disorders has markedly increased over the past few decades (Pawankar et al.,
2012). Allergic disorders are associated with neuropsychiatric conditions, such as attention-deficit and hyperactivity disorder, autism spectrum disorder, and asthmatic amyotrophy (Hopkins' syndrome) (Hopkins, 1974; Roth et al., 1991; Liedholm et al.,
Received June 21, 2016; revised Sept. 23, 2016; accepted Sept. 27, 2016.

Author contributions: R.Y., M.A.K., T.M., and J.-i.K. designed research; R.Y., T.F., B.W., K.M., M.Y., and J.-i.K. performed research; R.Y., T.F., B.W., K.M., M.A.K., T.M., M.Y., and J.-i.K. analyzed data; R.Y., B.W., and J.-i.K. wrote the paper.

This study was supported in part by Health and Labour Sciences Research Grants on Comprehensive Research on Disability Health and Welfare, Japan (H24-26-Shinkei-Kin-Ippan-001), "Glial assembly" Grant-in-Aid for Scientific Research on Innovative Areas (FY2013-2017) from the Ministry of Education, Culture, Sports, Science and Technology, Japan, and a Grant-in-Aid for Scientific Research (C) (25461282).

K.M. was supported as follows: Grants/Grants pending, Bayer Schering Pharma, Biogen Idec, Novartis Pharma, Mitsubishi Tanabe Pharma. J.-i.K. was supported as follows: consultancy, Biogen Japan and Novartis Pharma AG; honoraria, Bayer Healthcare, Otsuka Pharmaceutical, Novartis Pharma KK and Mitsubishi Tanabe Pharma
Corporation; Grants/Grants pending, the Ministry of Health, Labour and Welfare, Japan, the Science and Technology Agency, and the Ministry of Education, Culture, Sports, Science, and Technology, Japan, Japan Blood Products Organization, Takeda Pharmaceutical Ltd; speaking fees, Bayer Healthcare, Mitsubishi Tanabe Pharma, Otsuka Pharmaceutical, Novartis Pharma KK; travel expenses, Bayer Healthcare. The remaining authors declare no competing financial interests.

Correspondence should be addressed to Dr. Jun-ichi Kira, Department of Neurology, Neurological institute, Kyushu University Faculty of Medical Sciences, 3-1-1 Maidashi, Higashi-Ku, Fukuoka City, Fukuoka, 812-8582, Japan. E-mail: kira@neuro.med.kyushu-u.ac.jp.

D0I:10.1523/JNEUROSCI.1981-16.2016

Copyright $\odot 2016$ the authors $\quad 0270-6474 / 16 / 3611929-17 \$ 15.00 / 0$ 
Table 1. Description of antibodies used in the present study

\begin{tabular}{|c|c|c|c|}
\hline Name & Animal, clone & Manufacturer & Concentration \\
\hline ET-1 & Rabbit, polyclonal & Abcam & $2.0 \mu \mathrm{g} / \mathrm{ml}$ \\
\hline EDNRA & Rabbit, polyclonal & Abcam & 1:1000 dilution \\
\hline EDNRB & Rabbit, polyclonal & Gene Tex & $2.0 \mu \mathrm{g} / \mathrm{ml}$ \\
\hline $\mathrm{ECP}$ & Rabbit, polyclonal & Aviscera Bioscience & $2.5 \mu \mathrm{g} / \mathrm{ml}$ \\
\hline FOSB & Rabbit, monoclonal & Cell Signaling Technology & 1:50 dilution \\
\hline GFAP for human sample & Mouse, monoclonal & Dako Cytomation & 1:100 dilution \\
\hline GFAP for human sample & Rabbit, polyclonal & Dako Cytomation & 1:1000 dilution \\
\hline GFAP for mouse & Mouse, monoclonal & Chemicon International & $1.0 \mu \mathrm{g} / \mathrm{ml}$ \\
\hline GFAP for mouse & Rabbit, polyclonal & Novus Biologicals & $2.5 \mu \mathrm{g} / \mathrm{ml}$ \\
\hline ICAM-1 & Rat, monoclonal & Abcam & $1.0 \mu \mathrm{g} / \mathrm{ml}$ \\
\hline IRF8 & Goat, polyclonal & Santa Cruz Biotechnology & $0.4 \mu \mathrm{g} / \mathrm{ml}$ \\
\hline lba1 & Rabbit, polyclonal & Wako Pure Chemicals Industries & $1.0 \mu \mathrm{g} / \mathrm{ml}$ \\
\hline Mouse serum albumin & Rabbit, polyclonal & Abcam & $0.5 \mu \mathrm{g} / \mathrm{ml}$ \\
\hline Myelin basic protein (MBP) & Rabbit, polyclonal & Immuno-Biological Laboratory & 1:1000 dilution \\
\hline Neurofilament H (NF-H) Phosphorylated (clone SMI - 31) & Mouse, monoclonal & BioLegend & $1.0 \mu \mathrm{g} / \mathrm{ml}$ \\
\hline Neurofilament H (NF-H) Nonphosphorylated (clone SMI - 32) & Mouse, monoclonal & Covance & $1.0 \mu \mathrm{g} / \mathrm{ml}$ \\
\hline Neuronal nuclei (NeuN) & Mouse, monoclonal & Chemicon International & 1:1000 dilution \\
\hline$S 100 \beta$ & Rabbit, monoclonal & Abcam & $2.0 \mu \mathrm{g} / \mathrm{ml}$ \\
\hline
\end{tabular}

A

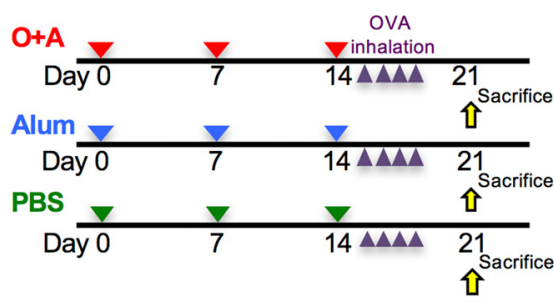

C

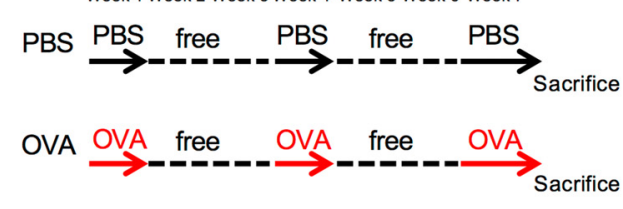

B

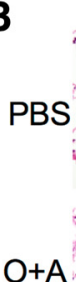

D

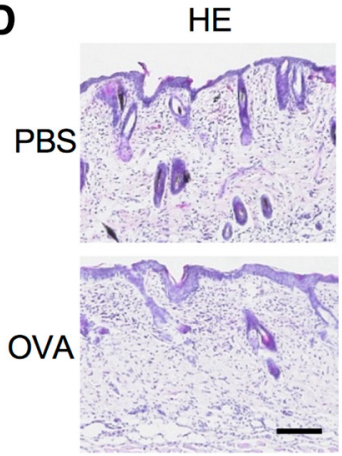

HE

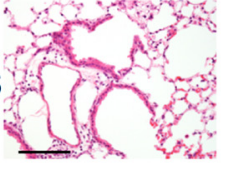

$\mathrm{O}+\mathrm{A}$

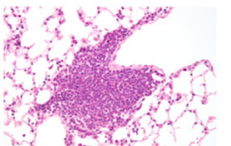

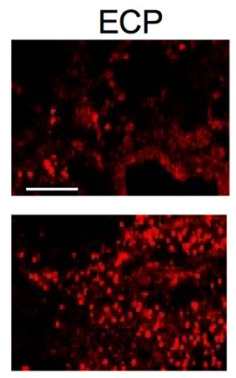

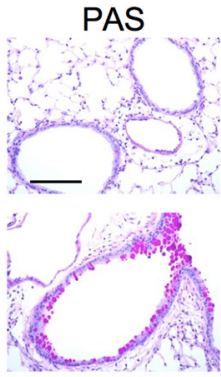

ECP

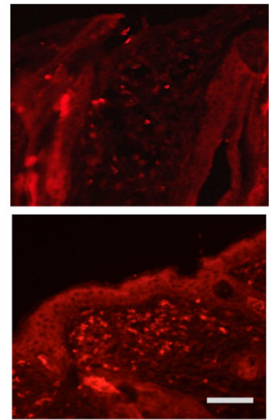

Figure 1. Protocols for producing atopy models and allergic inflammation in lung and skin tissues of atopy model mice. $\boldsymbol{A}$, Induction protocol of bronchial asthma in mice. Top line indicates a schematic figure for the $0+A$-treated group. Second and third lines indicate the Alum group and PBS group, respectively. $\boldsymbol{B}$, Histochemical analysis of lung tissues in $0+A$ and PBS groups. In the $0+A$ group, robust infiltration of inflammatory cells in the bronchi is evident (first row). Among the infiltrated inflammatory cells, there are abundant eosinophil cationic protein (ECP)-positive eosinophils (red) (second row). Periodic acid-Schiff(PAS) staining also demonstrates mucus overproduction and goblet cell hyperplasia in the $0+A$ group (third row). Scale bar, $50 \mu \mathrm{m}$. C, Schematic figure for atopic dermatitis induction. Top row, PBS control. Bottom row, Atopic dermatitis model. $\boldsymbol{D}$, Skin histology of PBS-swabbed and OVA-swabbed mice. OVA-swabbed mouse skin shows thickening of the epidermis and dermis (first row) and numerous ECP-positive (red) eosinophils infiltrating into the dermis (second row). Scale bars: H\&E, $100 \mu \mathrm{m}$; ECP, $50 \mu \mathrm{m}$.

1994; M.H. Chen et al., 2014). However, it is unknown how allergic inflammation causes neuropsychiatric dysfunction. We and others have reported the emergence of a peculiar form of myelitis presenting with persistent neuropathic pain, specifically allodynia, as a cardinal symptom in patients with atopic disorders, such as atopic dermatitis, allergic rhinitis, and atopic asthma, in Japan and Korea (Kira et al., 1997, 1998, 2008; Murai et al., 2004; Ochi et al., 2004; Yoon et al., 2009; Ainiding et al., 2012; Kanamori et al., 2013). These patients with myelitis and atopy showed specific increases in $\mathrm{C}-\mathrm{C}$ motif chemokine 11 and interleukin-9 in the CSF (Tanaka et al., 2008). Nationwide surveys have repeatedly revealed widespread occurrence of this form of myelitis in Japan (Osoegawa et al., 2003a; Isobe et al., 2009), and similar cases were also reported worldwide, including Western countries (Zoli et al., 2005; Constantinescu et al., 2006; Gregoire et al., 2006; Isaacs et al., 2011). Neuropathological studies of biopsied spinal cord lesions from patients with atopy and chronic persistent myelitis revealed active inflammation with loss of myelin and axons, accompanied with varying degrees of eosinophil infiltration (Kikuchi et al., 2001; Osoegawa et al., 2003b). Thus, the term "atopic myelitis" was introduced, together with the diagnostic criteria (Isobe et al., 2012). Atopic myelitis develops in a fraction of atopy sufferers possessing susceptibility genes, such as HLA-DRB1 ${ }^{\star} 02: 01$ (Sato et al., 2012). However, the relationship 
A

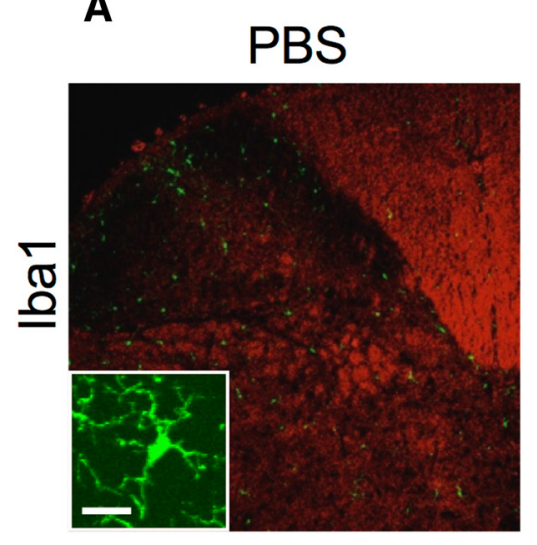

B

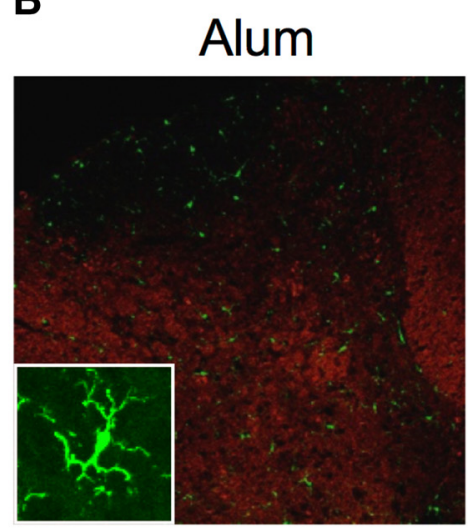

C

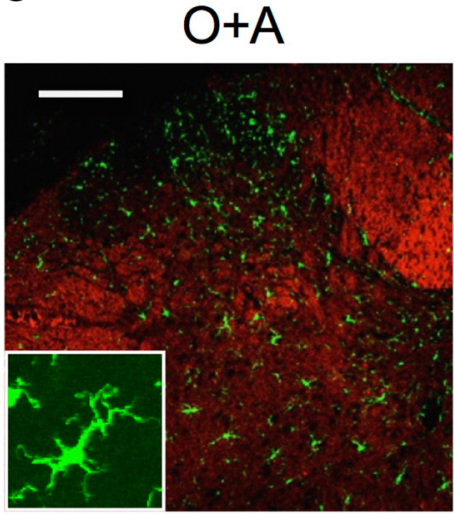

D

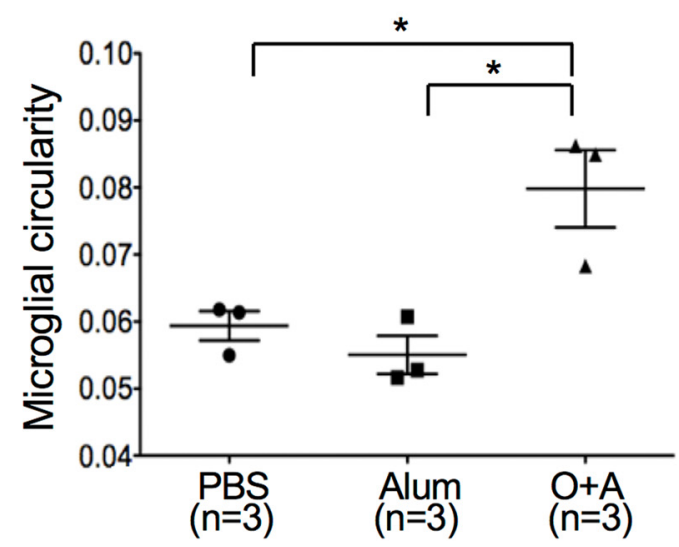

E

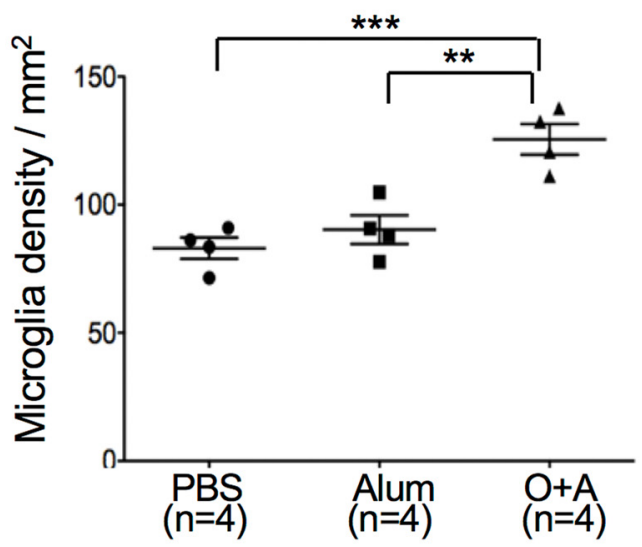

Figure 2. Microglial activation in bronchial asthma model mice. $A-C$, Immunohistochemistry of the lumbar spinal cord for microglia (green) stained with anti-ionized $\mathrm{Ca}^{2+}$ binding adapter molecule 1 (lba1) antibody followed by FluoroMyelin staining (red) from PBS- (A), Alum- (B), and 0+A-pretreated mice (C). Scale bar, $100 \mu \mathrm{m}$. Scale bar: inset, $20 \mu \mathrm{m}$. $\boldsymbol{D}$, Microglial cell density. $E$, Microglial cell circularity. ${ }^{*} p<0.05$ (Tukey's post test after one-way ANOVA). ${ }^{* *} p<00.01$ (Tukey's post test after one-way ANOVA). ${ }^{* * *} p<0.001$ (Tukey's post test after one-way ANOVA).

between allergic inflammation and allodynia, and the underlying mechanism for allodynia in this condition, remain to be elucidated.

The aim of this study was to determine how atopy exerts substantial influence on the nociceptive system. We first studied the influence of atopy on spinal cord microglia and astroglia in atopy model mice because both types of glia play critical roles in induction and maintenance of persistent neuropathic pain in peripheral nerve injury (PNI) animal models (Tsuda et al., 2003; G. Chen et al., 2014). We found that atopy model mice had severe allodynia with glial inflammation in the spinal cords. Development of allodynia was successfully prevented by administration of a selective endothelin-1 (ET-1) receptor Type B (EDNRB) antagonist with attenuation of glial activation. We then extended our study to humans and detected elevation of serum ET-1 levels and activation of spinal microglia and astroglia with upregulation of EDNRB in patients with atopy and myelitis of unknown cause, predominantly presenting with neuropathic pain. These results suggest a previously unrecognized mechanism whereby atopy induces glial activation and neuropathic pain via an ET-1/EDNRB pathway, which might be a potential therapeutic target for atopyrelated neuropathic pain.

\section{Materials and Methods}

Mice. Six-week-old C57BL/6 male mice were obtained from KBT Oriental and used for all experimental procedures. $C \mathrm{cr} 2^{\mathrm{rfp} /+} \mathrm{C} \times 3 \mathrm{cr} 1^{\mathrm{gfp} /+}$ mice were generated by crossbreeding B6.129(Cg)-Ccr2tm2.1Ifc/J mice (https://www.jax.org/strain/017586; The Jackson Laboratory) with B6.129P-CX3crltml Litt/J mice (https://www.jax.org/strain/005582; The Jackson Laboratory). Each strain was backcrossed for five generations with a C57BL/6 background.

Animal models of atopic diathesis, asthma, and atopic dermatitis. For the induction of atopic diathesis, we used three different models of atopy: atopic diathesis alone without atopic lesions, bronchial asthma, and atopic dermatitis. Both bronchial asthma and atopic dermatitis were reported to be the most frequent comorbidities of atopic myelitis (Osoegawa et al., 2003a; Isobe et al., 2009). To induce atopic diathesis, 6-weekold C57BL/6 male mice were intraperitoneally injected with ovalbumin (OVA) $(50 \mu \mathrm{g})$ and aluminum hydroxide hydrate (Alum) (2 mg) dissolved in $200 \mu \mathrm{g}$ of PBS on days 0, 7, and 14 (O+A group) (Nials and Uddin, 2008). The PBS-injected group (PBS group) and Alum-injected group (Alum group) were controls. Thereafter, bronchial asthma was induced by direct nasal aspiration of OVA solution $(2.5 \mathrm{mg} / \mathrm{ml})$ for 4 consecutive days (days 15-18) (see Fig. 1A). On day 21, these mice were subjected to further examinations. To investigate whether peripheral immune cells infiltrated the tissue, bronchial asthma was induced in $\mathrm{Ccr} 2{ }^{\mathrm{rfp} /+} \mathrm{Cx} 3 \mathrm{cr}^{1}{ }^{\mathrm{gfp} /+}$ mice using the same procedure described above. To produce atopic dermatitis (Spergel et al., 1998), 6-week-old female C57BL/6 mice were anesthetized by sevoflurane, and the back skin at the thoracic spinal cord levels (between both scapulae) was shaved and tapestripped six times with transparent tape to give a mild skin-scratch injury. A gauze patch $(1 \mathrm{~cm} \times 1 \mathrm{~cm})$ soaked with either $100 \mu \mathrm{g}$ OVA or $100 \mu \mathrm{l}$ of PBS was placed on the back and covered by a transparent dressing. A covering was placed 1 week later and kept in place for 2 weeks, and covered again using the same procedure. After repeating once more (6 
A

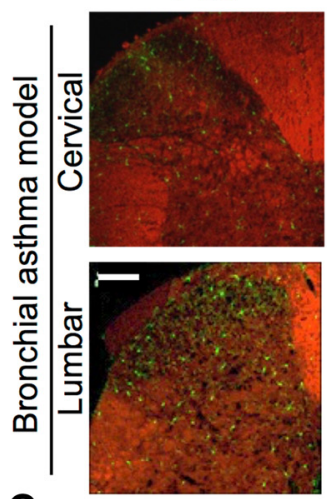

C

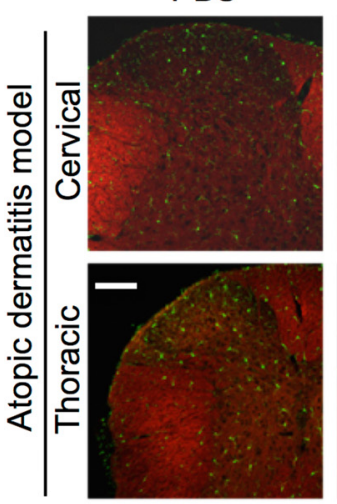

E

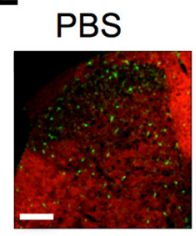

$O+A$

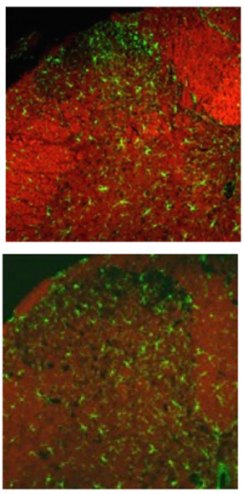

$\mathrm{O}+\mathrm{A}$
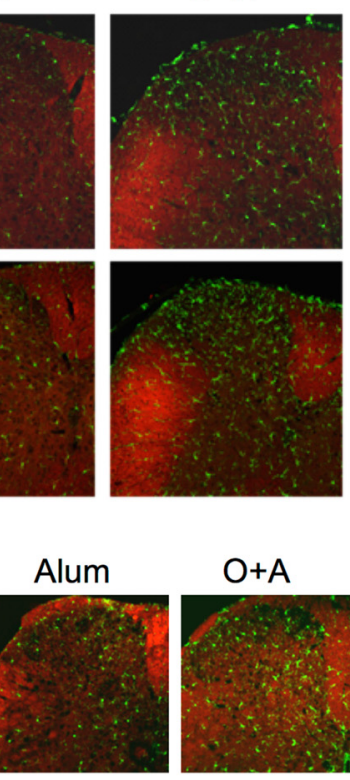

$\mathrm{O}+\mathrm{A}$

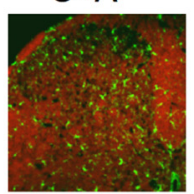

D

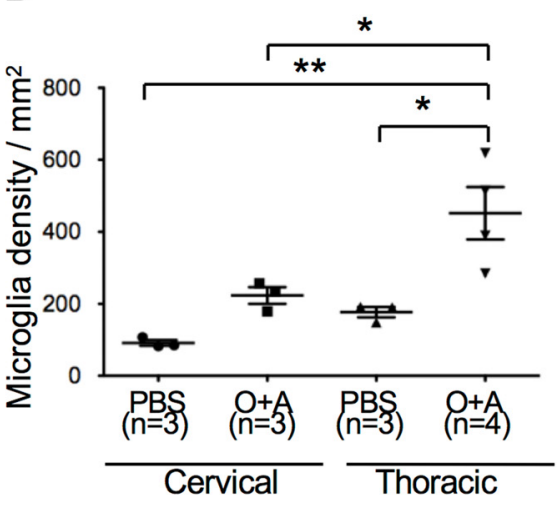

$\mathbf{F}$

B
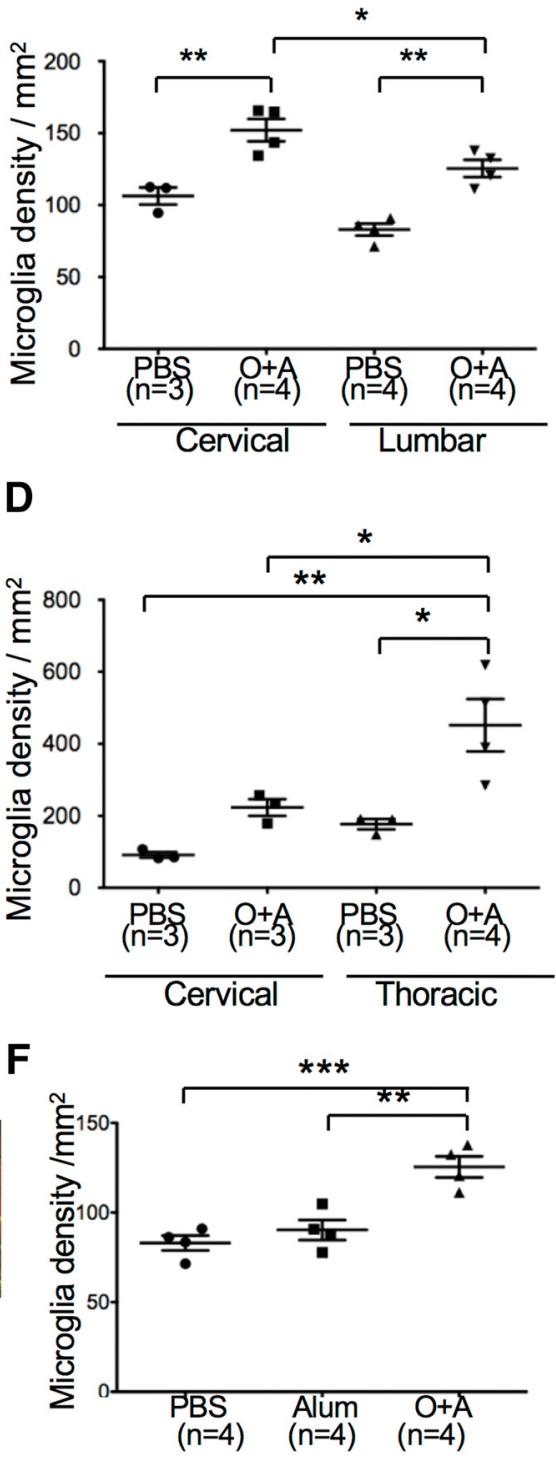

G

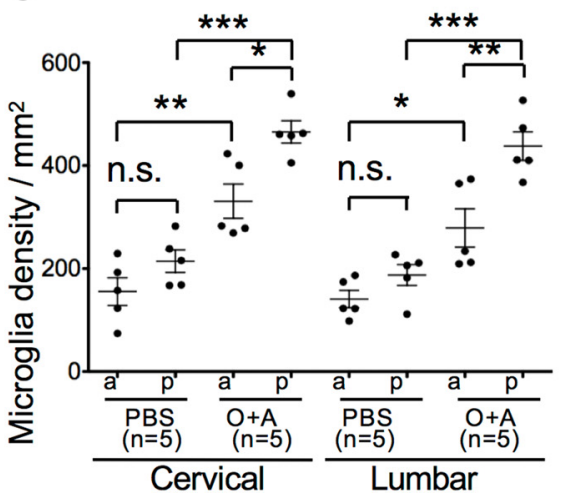

H

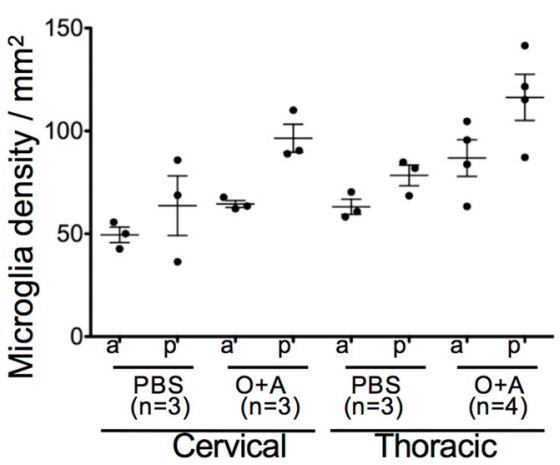

Figure 3. Microglia activation in distinct sites of the spinal cord from mice with bronchial asthma or atopic dermatitis on the back skin at the thoracic spinal cord levels (between both scapulae). $A, C$, Immunohistochemistry of the cervical and lumbar spinal cord for microglia (green) stained with anti-Iba1 antibody followed by FluoroMyelin staining (red) in mice with asthma $(\boldsymbol{A})$ or atopic dermatitis (C). Scale bars, $100 \mu \mathrm{m}$. $\boldsymbol{B}, \boldsymbol{D}$, Comparison of microglial density was made between the cervical and lumbar cord levels in asthma model mice $(\boldsymbol{B})$ and atopic dermatitis model mice $(\boldsymbol{D})$. $\boldsymbol{E}$, Immunohistochemistry of the lumbar spinal cord for microglia (green) stained with anti-lba1 antibody followed by FluoroMyelin staining (red) from PBS-treated, Alum-treated, and $0+$ A-treated mice without induction of bronchial asthma. Scale bar, $100 \mu \mathrm{m}$. $\boldsymbol{F}$, Quantification of microglial cell density in PBS-treated, Alum-treated, and $0+$ A-treated mice without induction of bronchial asthma. There is a significant increase in microglia density in the $0+$ A group compared with the PBS-treated and Alum-treated groups. $\mathbf{G}, \boldsymbol{H}$, Microglia density according

weeks later), the mice were treated again for $7 \mathrm{~d}$ and killed for further experiments (see Fig. 1C).

Preventive therapy. To prevent the emergence of glial activation and allodynia in bronchial asthma model mice, 18 mice were divided into three groups: PBS-pretreated group $(n=$ 6), OVA and Alum $(\mathrm{O}+\mathrm{A})$-pretreated group $(n=6)$, and preventive therapy group $(n=6)$. In the preventive therapy group, mice were first subjected to daily intraperitoneal injection of BQ-788 (1 mg/kg/d) (Lo et al., 2005) $7 \mathrm{~d}$ before the start of induction of atopic diathesis and asthma (intraperitoneal $\mathrm{O}+\mathrm{A}$ injection followed by OVA inhalation) until day 19 (total 27 d) (see Fig. 12A). On day 19, the presence of allodynia was assessed by von Frey filaments, and mice were killed afterward and used for further experiments.

von Frey testing. Tactile allodynia was assessed using calibrated von Frey filaments (0.04-0.4 g; Aesthesio, DanMic Global) (Chaplan et al., 1994). Mice were placed in a black plastic cage with a wire mesh bottom, which allowed access to the paws. Behavioral acclimatization was allowed for $1 \mathrm{~h}$ until cage exploration and grooming activities ceased. The area tested was the midplantar hindpaw. The von Frey filament was presented perpendicular to the plantar surface with sufficient force to cause slight buckling against the paw, and held for 4-6 s. Stimuli were presented at intervals of over $10 \mathrm{~s}$. Each filament was presented 10 times, and the number of positive responses multiplied by 10 was recorded as the percent response (Chaplan et al., 1994).

Histological and immunohistochemical analyses. Mice were deeply anesthetized with sevoflurane and perfused transcardially with PBS followed by ice-cold 4\% PFA with saturated picric acid. The lungs, skin, and spinal cords were removed and processed for paraffin or frozen sectioning. Lung and skin paraffin sections $(3 \mu \mathrm{m})$ were stained with $\mathrm{H} \& \mathrm{E}$ and periodic acid-Schiff. To prepare frozen sections, the lungs, skin, and spinal cord samples were placed in $15 \%$ sucrose in PBS solution and then $30 \%$ sucrose for $24 \mathrm{~h}$ at $4^{\circ} \mathrm{C}$. To assess the effect of sensory input from the trachea, $\mathrm{Cl}$ level portions of spinal cords were collected and sectioned. Likewise, Th4 and L5 levels were used to analyze sensory inputs from the upper back and hindpaw. Transverse spinal cord sections $(20 \mu \mathrm{m})$ or lung or skin sections $(10 \mu \mathrm{m})$ were cut on a Leica CM 1850 cryostat and incubated for $2 \mathrm{~h}$ at room temperature in a block-

to the location of the spinal cord in PBS-pretreated and $0+A$ pretreated asthma model mice $(\boldsymbol{G})$ and atopic dermatitis model mice $(\boldsymbol{H})$. The increase in microglia is more prominent in the posterior ( $\mathrm{p}$ ) region than in the anterior (a) region in mice with asthma ( $0+A$ group). The same trends, as seen in asthma model mice $(\boldsymbol{G})$, are also observed in atopic dermatitis model mice $(\boldsymbol{H})$, which do not reach statistical significance because of the small sample size. ${ }^{*} p<0.05$ (Tukey's post test after one-way ANOVA). ${ }^{* *} p<0.01$ (Tukey's post test after one-way ANOVA). ${ }^{* * *} p<0.001$ (Tukey's post test after oneway ANOVA). 


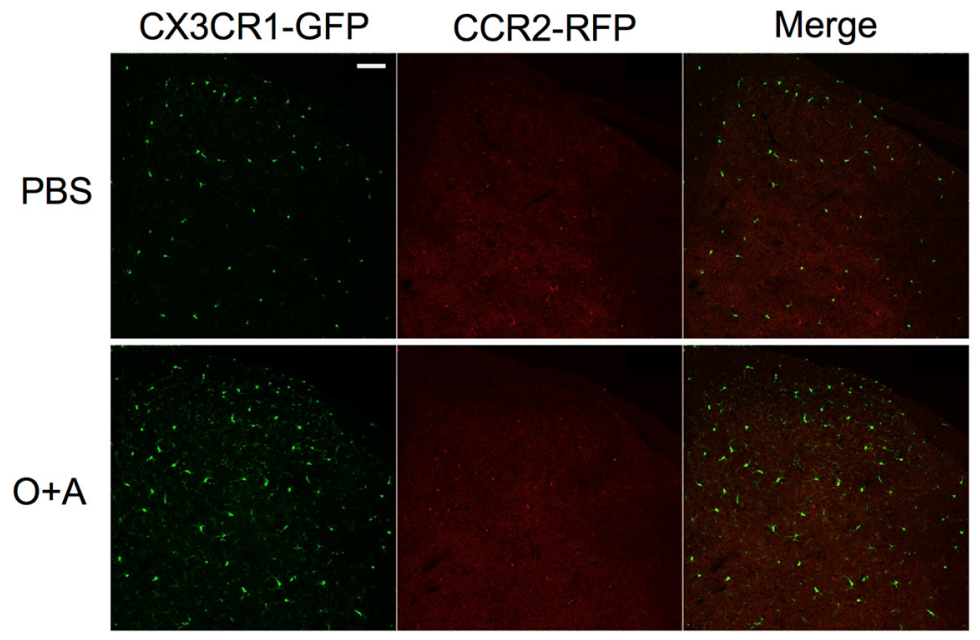

Figure 4. Immunohistochemistry for peripheral blood-born macrophage infiltration. $\mathrm{Ccr} 2^{\mathrm{rfp} /+} \mathrm{Cx} 3 \mathrm{Cr}^{\text {gfp } /+}$ mice, in which peripheral blood macrophages are labeled by red fluorescent protein (RFP) whereas microglia are labeled by GFP (Yamasaki et al., 2014). These mice were used to elucidate the contribution of peripheral blood immune cells. There are no RFP-positive cells in either the PBS-pretreated or OVA and Alum (0+A)-pretreated asthma mice. Scale bar, $100 \mu \mathrm{m}$.

A
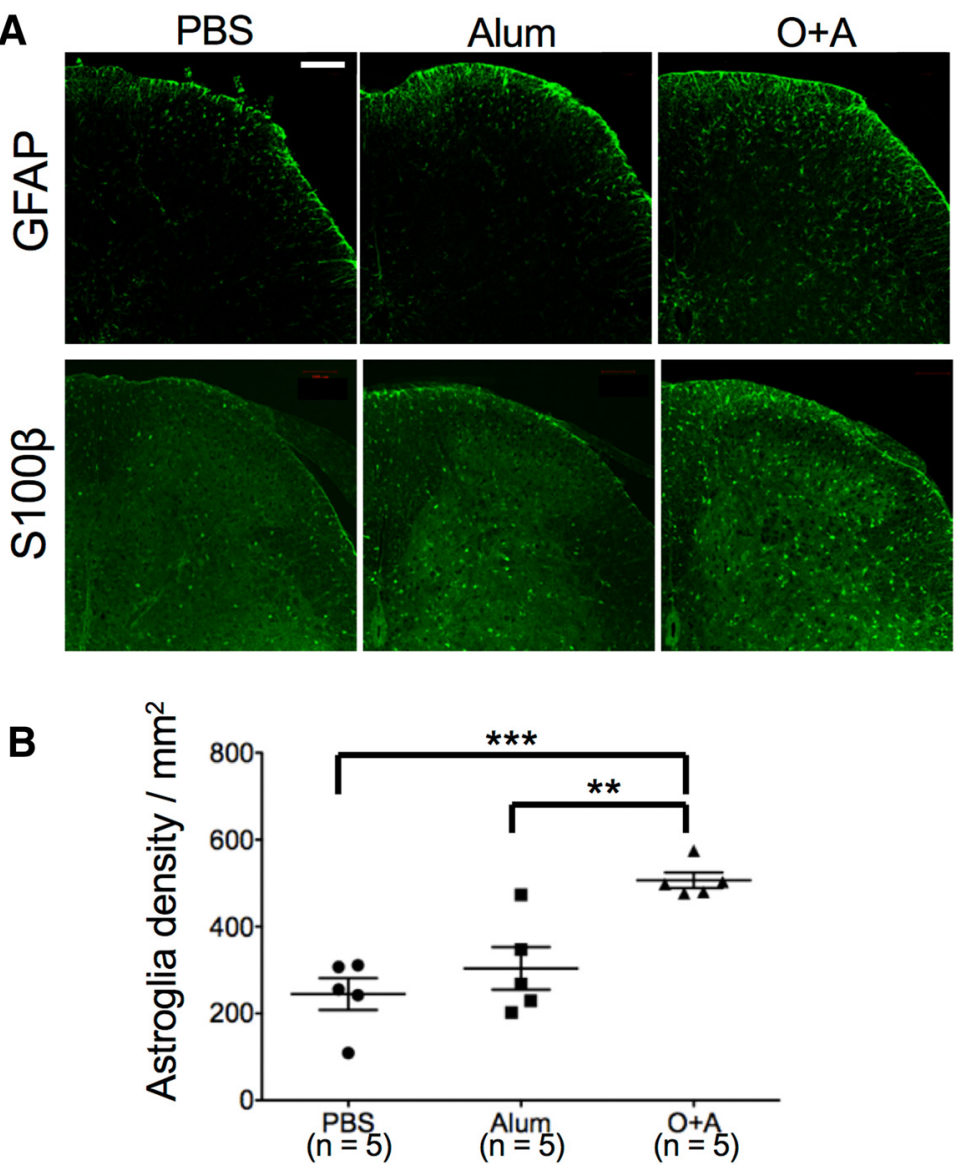

Figure 5. Astroglial activation in bronchial asthma model mice. $A$, Immunostaining of the lumbar spinal cord with anti-GFAP antibody and anti-S100 $\beta$ antibody from PBS, Alum, and $0+A$-pretreated mice. B, Astroglial cell density. ${ }^{* *} p<0.01$ (Tukey's post test after one-way ANOVA). ${ }^{* *} p<0.001$ (Tukey's post test after one-way ANOVA). Scale bar, $100 \mu \mathrm{m}$.

ing solution (10\% normal goat serum), and then incubated for $48 \mathrm{~h}$ at $4^{\circ} \mathrm{C}$ with primary antibodies. The primary antibodies used are listed in Table 1. Tissues were incubated with secondary antibodies conjugated to AlexaFluor-488 or -594 (1:1000, Thermo Fisher) and mounted with Prolong gold with DAPI (Thermo Fisher). FluoroMyelin Red (Thermo Fisher) was applied for $20 \mathrm{~min}$ at room temperature after the secondary antibody. Tissues were observed with an LSM 510 Meta confocal microscope (Carl Zeiss).

Cell counting. The modified optical dissector method was used as described previously (Yamasaki et al., 2007). Briefly, six 20- $\mu$ m-thick slices for each region were randomly selected; and after samples for immunohistochemical studies were prepared, the digital images were collected. Each cell type labeled by a specific antibody was then automatically counted by FIJI software (National Institutes of Health, Bethesda, MD). For the differential cell density measurement, transverse sections of the spinal cord were divided into the anterior and posterior regions by a horizontal line through the central canal. Counted cell numbers were divided by the area to calculate cell density, and mean values for each mouse were calculated.

Image morphometric analysis. ImageJ software was used to measure area $(\mathrm{S})$ and perimeter $(\mathrm{L})$ of each microglial cell. Circularities of microglia were calculated as follows: circularity $=4 \pi \mathrm{S} / \mathrm{L} 2$. The cells with a circularity close to 1 were regarded to have a morphology close to round cells, which indicates an activated state.

Sorting of microglial cells and RNA array assay. Spinal cords were removed from mice with and without atopic diathesis, and homogenized by Dounce homogenizer. Mononuclear cells were isolated with a 30\%/70\% Percoll (GE Healthcare) gradient, as previously described (Cardona et al., 2006). Collected mononuclear cells were stained with anti-F4/80-phycoerythrin (BM8; iCyt) and CD45-PerCP (30-F11, Sony Biotechnology). Cells were sorted on a Sony SH-800 by gating on $\mathrm{F} 4 / 80^{+} \mathrm{CD} 45^{\mathrm{dim}}$ as microglia. Sorted cells were harvested directly in RNAlater Stabilization Solution (AM7020, Thermo Fisher) and subjected to RNA array assay.

Total RNA isolation. Total RNA was isolated from sorted microglial cells using TRIzol Reagent (Thermo Fisher) and purified using SV Total RNA Isolation System (Promega) according to the manufacturer's instructions. RNA samples were quantified by an ND-1000 spectrophotometer (NanoDrop Technologies), and the quality was confirmed with an Experion System (Bio-Rad Laboratories).

Gene expression microarrays. Total RNA (5 ng) was used for amplification with Ovation RNA Amplification System V2 (NuGEN Technologies). One microgram of purified, amplified cDNA was used as input into the Genomic DNA Enzymatic Labeling Kit (Agilent Technologies). The amplification and labeling reactions were performed according to the manufacturer's instructions. Labeled cDNAs were hybridized to a $60 \mathrm{~K}$ Agilent 60-mer oligomicroarray (SurePrint G3 Mouse Gene Expression Microarray $8 \times 60 \mathrm{~K}$, Agilent Technologies), according to the manufacturer's instructions. All hybridized microarray slides were scanned by an Agilent scanner; relative hybridization intensities and background hybridization values were calculated using Agilent Feature Extraction Software (9.5.1.1, Agilent Technologies).

Data analysis and filter criteria. Raw signal intensities and flags for each probe were calculated from hybridization intensities (gProcessedSignal), and spot information, according to the procedures recommended by Agilent 
A

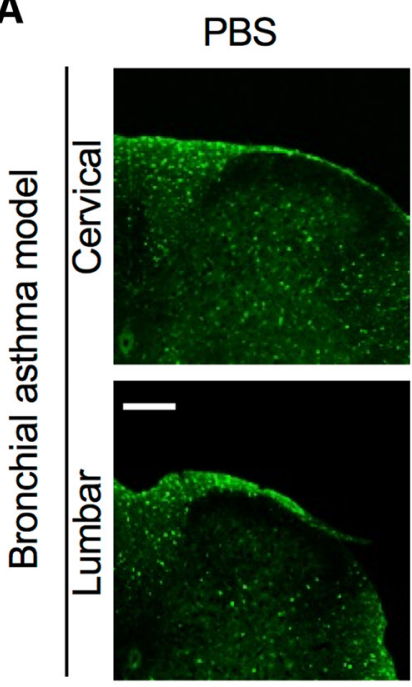

C
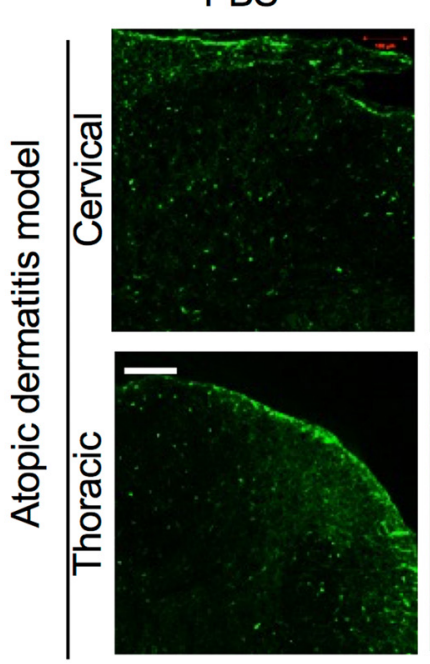

E

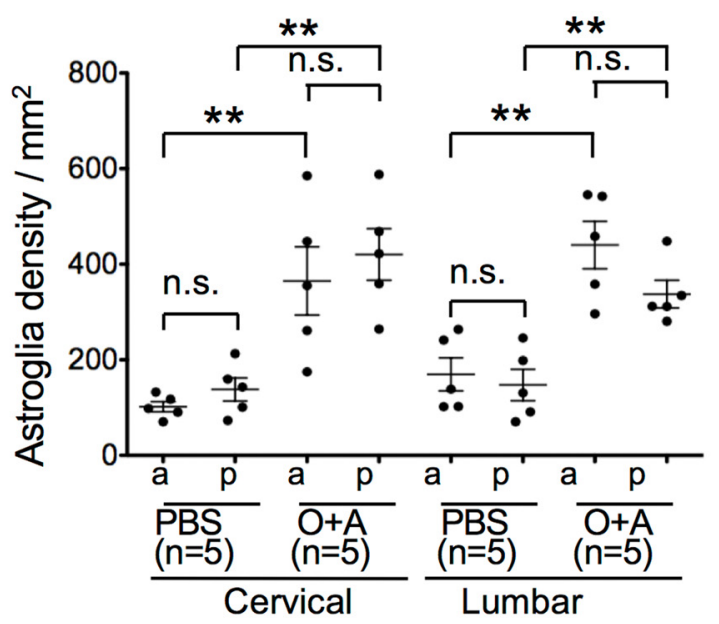

B
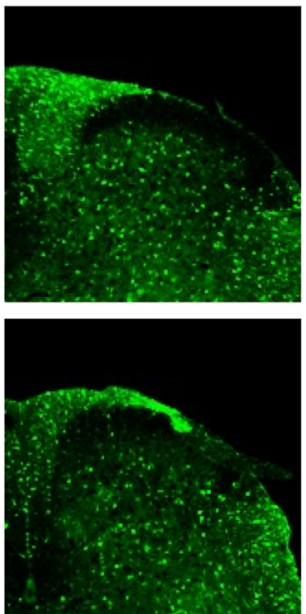

$\mathrm{O}+\mathrm{A}$
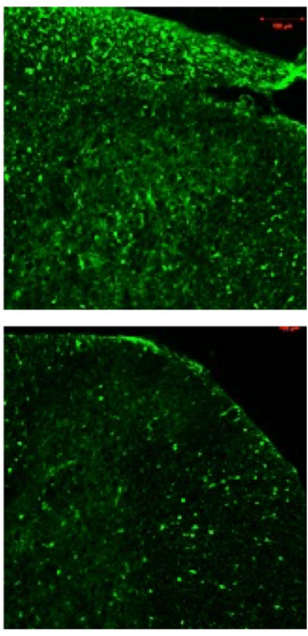

D

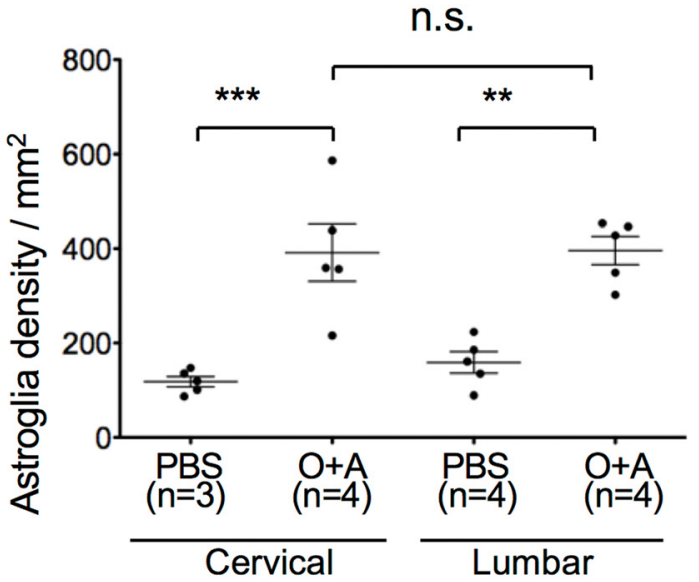

n.s.

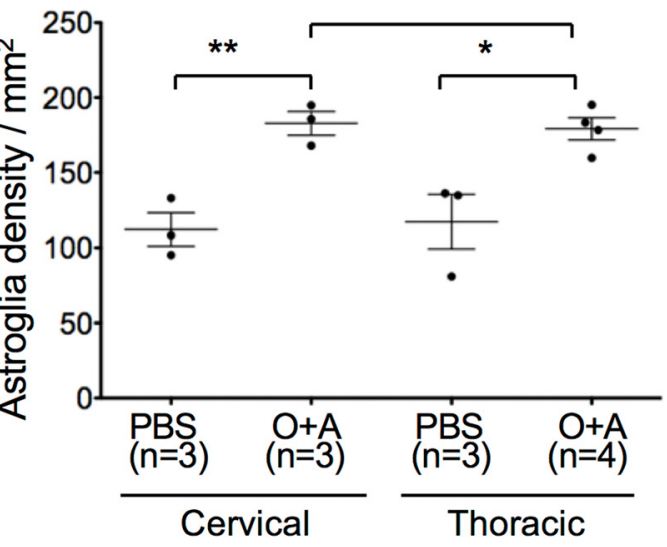

F

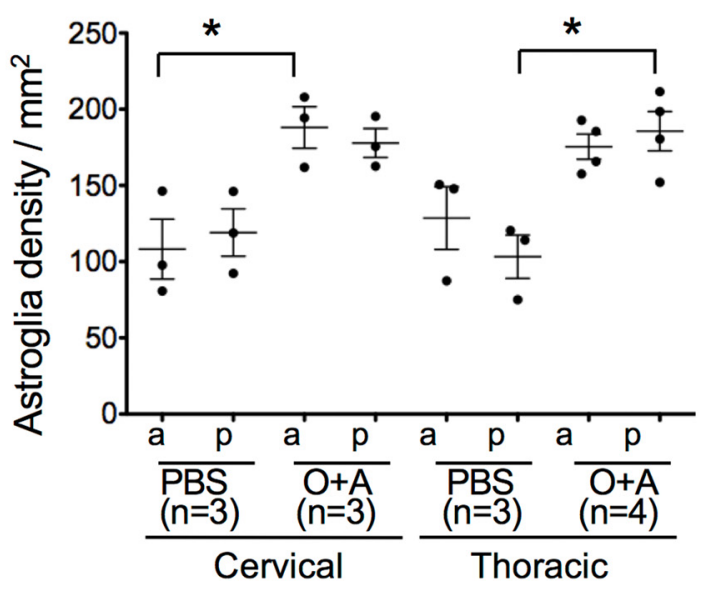

Figure 6. Astroglial activation in distinct sites of the spinal cord from mice with bronchial asthma or atopic dermatitis on the back skin at the thoracic spinal cord levels (between both scapulae). $\boldsymbol{A}, \boldsymbol{C}$, Immunohistochemistry of the cervical and lumbar spinal cord for astroglia stained with anti-S100 $\beta$ antibody in mice with asthma $(\boldsymbol{A})$ or atopic dermatitis $(\boldsymbol{C})$. Scale bars, $100 \mu \mathrm{m} . \boldsymbol{B}, \boldsymbol{C}$, Comparison of astroglial density was made between the cervical and lumbar spinal cord levels in asthma model mice $(\boldsymbol{B})$ and atopic dermatitis model mice $(\boldsymbol{D})$. $\boldsymbol{E}, \boldsymbol{F}$, Astroglial density according to the location of the spinal cord in PBS-pretreated and $0+A$-pretreated asthma model mice $(\boldsymbol{E})$ and atopic dermatitis model mice $(\boldsymbol{F})$. Unlike microglia, astroglia density is similar between the anterior and posterior regions in both models. a, Anterior region; $\mathrm{p}$, posterior region; PBS, control mice; $0+\mathrm{A}$, bronchial asthma mice. ${ }^{*} p<0.05$ (Tukey's post test after one-way ANOVA). ${ }^{* *} p<0.01$ (Tukey's post test after one-way ANOVA). ${ }^{* * *} p<0.001$ (Tukey's post test after one-way ANOVA). 
A

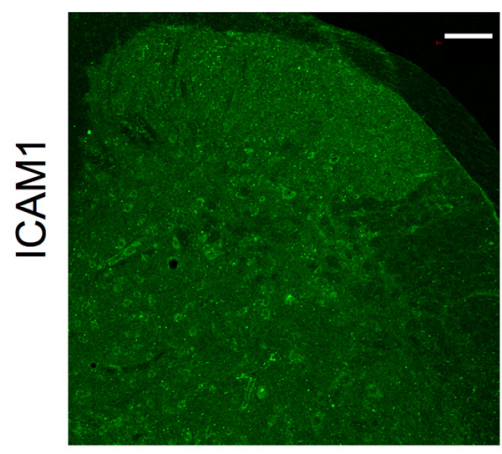

PBS

B

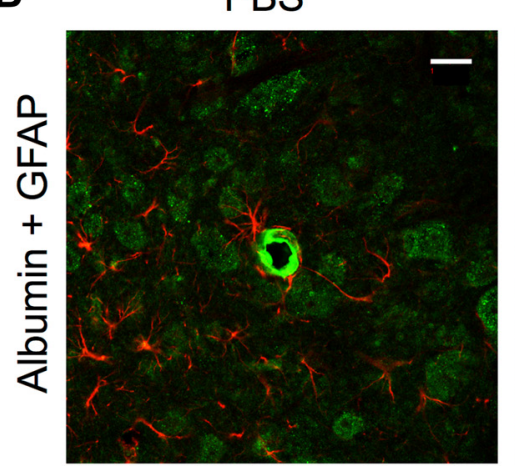

$\mathrm{O}+\mathrm{A}$
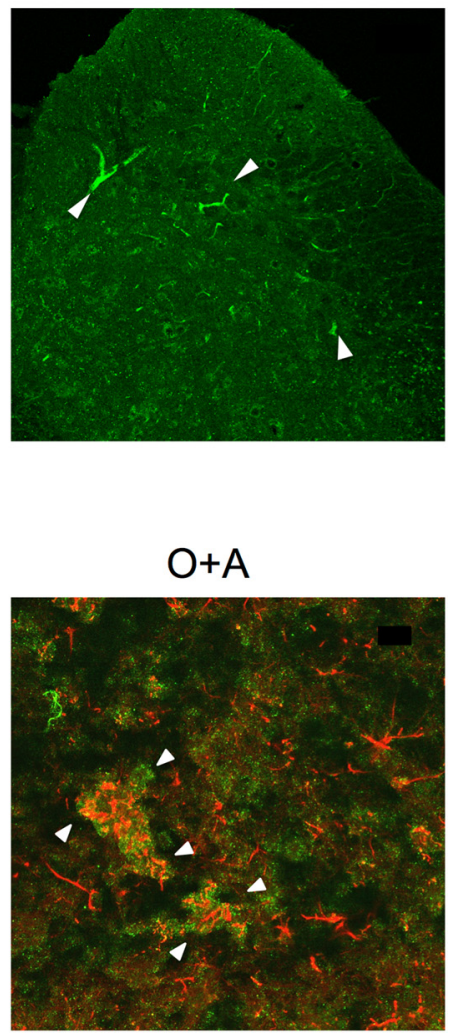

Figure 7. Immunohistochemistry for BBB integrity. $\boldsymbol{A}$, Lumbar spinal cord sections from a bronchial asthma model mouse stained with anti-intercellular adhesion molecule-1 (ICAM-1) antibody. Scale bar, $100 \mu \mathrm{m}$. B, Lumbar spinal cord sections from a bronchial asthma model mouse double-stained with anti-mouse albumin and anti-GFAP antibodies. Scale bar, $50 \mu \mathrm{m}$. In an $0+$ A-pretreated mouse with asthma, endothelial cells in the spinal cord become ICAM-1-positive (white arrowheads), and albumin leaks out of the vessels into the spinal cord parenchyma (white arrowheads).

Technologies (Flag criteria on GeneSpring Software): Absent (A): "Feature is not positive and significant" and "Feature is not above background"; Marginal (M): "Feature is not uniform," "Feature is saturated," and "Feature is a population outlier"; Present (P): others. The raw signal intensities of two samples were log2-transformed and normalized by quantile algorithm with Preprocess Core library package on Bioconductor software. We selected probes that call $\mathrm{P}$ flag in both samples. To identify upregulated or downregulated genes, we calculated $Z$ scores and ratios (non-log scaled fold-change) from the normalized signal intensities of each probe for comparison between the control and experiment samples. The $Z$ score was calculated from $\log 2$ fold-change $(\log \mathrm{FC})$ of the probes indicated the distance from average of the $\log \mathrm{FC}$ (if $Z$ score $=2$, then the $\log F C$ of the current probe had $2 \times \mathrm{SD}$ from the average.) We then established criteria for regulated genes: (upregulated genes) $Z$ score $\geq 2.0$ and ratio $\geq 1$.5-fold (downregulated genes) $Z$ score $\leq-2.0$ and ratio $\leq 0.66$.

Immunoblotting. Mice were anesthetized by sevoflurane and perfused transcardially with PBS. The spinal cords were immediately collected into 1.5 $\mathrm{ml}$ tubes, snap-frozen in liquid nitrogen, and stored at $-80^{\circ} \mathrm{C}$ until used. The soluble fraction prepared from the spinal cord homogenates by differential centrifugation were electrophoresed using SDS-polyacrylamide gels. Proteins on the gels were transferred electrophoretically at $100 \mathrm{~V}$ for $1 \mathrm{~h}$ onto nitrocellulose membranes and then incubated at $4^{\circ} \mathrm{C}$ overnight with a primary antibody against EDNRB and mouse albumin. After washing, the membranes were incubated with $0.5 \%$ HRP-labeled donkey anti-rabbit IgG. Subsequently, the membrane-bound antibodies were detected by an enhanced chemiluminescence detection kit: the ECL Western Blotting System (GE Healthcare) or Supersignal West Dura Extended Duration Substrate (Thermo Fisher) with an image analyzer (ChemiDoc XRS System, Bio-Rad). The protein bands were scanned and then analyzed by densitometry.
Patient samples and data collection. Autopsied spinal cord specimens of an atopy patient with idiopathic myelitis and neuropathic pain who met the established criteria for atopic myelitis with high specificity and sensitivity (both $>90 \%$ ) (Isobe et al., 2012) were obtained from the Department of Neuropathology, Institute for Medical Science of Aging, Aichi Medical University (Aichi, Japan). A 22-year-old woman developed weakness of her right leg, followed by dysesthesia (tactile allodynia) and neuropathic pain on both upper limbs. She had atopic dermatitis since she was 1-month-old and showed high titer IgE and upper cervical cord lesions on MRI. She developed quadriplegia despite intensive immunotherapy and died of septic shock 1 year and 2 months after the onset of myelitis. We obtained clinical data and sera from 20 patients with atopy and myelitis of unknown cause (atopic myelitis) according to the established criteria (Isobe et al., 2012) and 10 healthy controls. Written informed consent was obtained. There were no significant differences in age and sex. Subjects with atopic disorders were as follows: 20 of $20(100 \%)$ in atopic myelitis and 0 of $10(0 \%)$ in healthy controls. Fifteen patients (75\%) with atopic myelitis were taking antiallergic drugs.

Tissue preparations and immunohistochemistry for human spinal cord samples. Cervical cord samples were fixed in 10\% formalin and processed into paraffin sections ( $5 \mu \mathrm{m}$ thick). The primary antibodies for immunohistochemistry are listed in Table 1. All sections were deparaffinized in xylene and rehydrated through an ethanol gradient. Endogenous peroxidase activity was blocked with $0.3 \% \mathrm{H}_{2} \mathrm{O}_{2}$ /methanol. The sections were then incubated overnight with primary antibodies at $4^{\circ} \mathrm{C}$. After rinsing, the sections were treated with a streptavidinbiotin complex. Immunoreactivity was detected using DAB, and sections were counterstained with hematoxylin (Masaki et al., 2013). For double immunofluorescent staining, the designated primary antibodies were simultaneously added into the incubation buffer and incubated overnight at $4^{\circ} \mathrm{C}$. After rinsing, sections were incubated with AlexaFluor-488 or AlexaFluor-594 (Invitrogen) and then counterstained with DAPI. Images were captured using a confocal laser microscope system (Nikon A1, Nikon).

ELISA. ELISA kit (QuantiGlo; R\&D Systems) for detecting ET-1 was used for the measurement of ET-1 concentrations in human and mouse serum according to the manufacturer's protocol. Mouse IgE ELISA kit (Shibayagi) was also used for detection and quantification of mouse serum IgE level. Optical density for each well was measured at $450 \mathrm{~nm}$ by a luminometer (microplate reader MTP-800AFC, Yamato) set at the following parameters: $1.0 \mathrm{~min}$ lag time; $0.5 \mathrm{~s} /$ well reading time; summation mode; auto gain on, or equivalent.

Statistics. All data are presented as mean \pm SEM. The statistical significance of the difference between values was determined by one-way ANOVA with Tukey's post hoc analysis, two-way factorial ANOVA with Bonferroni's post hoc test, and the Mann-Whitney $U$ test. A value of $p<0.05$ was considered to be statistically significant.

Study approvals. Animal experiments were performed according to the protocols approved by the Institutional Animal Care and Use Committee at Kyushu University (\#A27-023). The research protocol for the retrospective study and the data privacy procedures for consented human samples were approved by the Kyushu University ethics committee (\#27-55). 
A

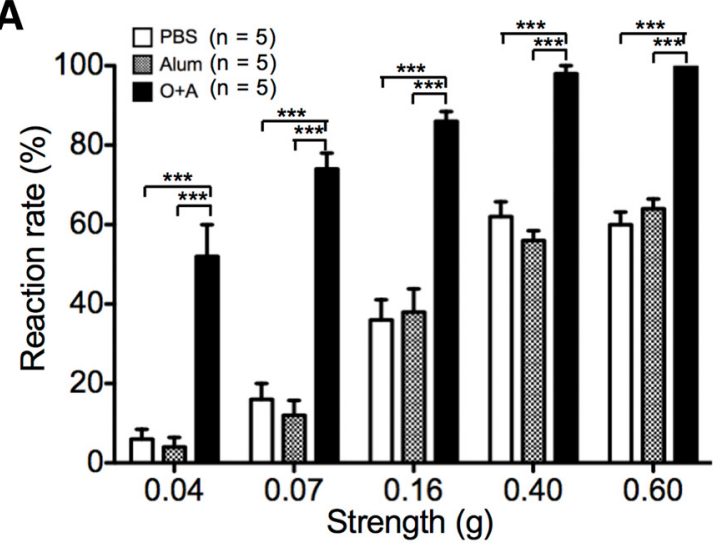

C
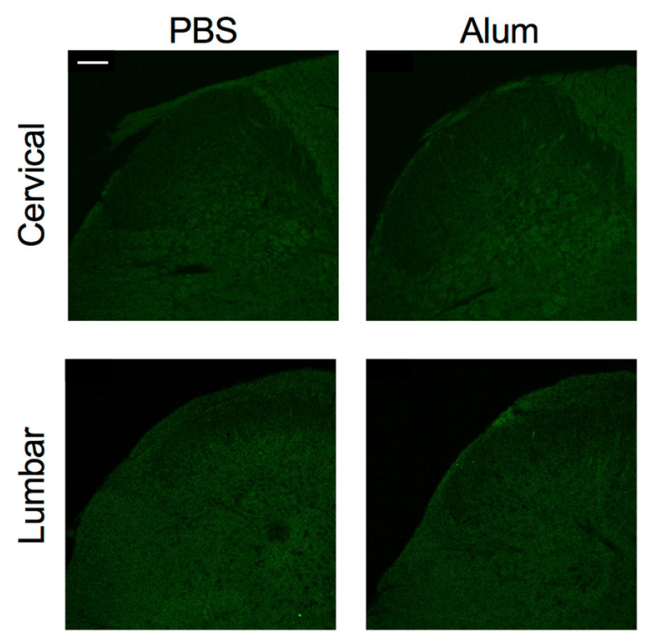

D

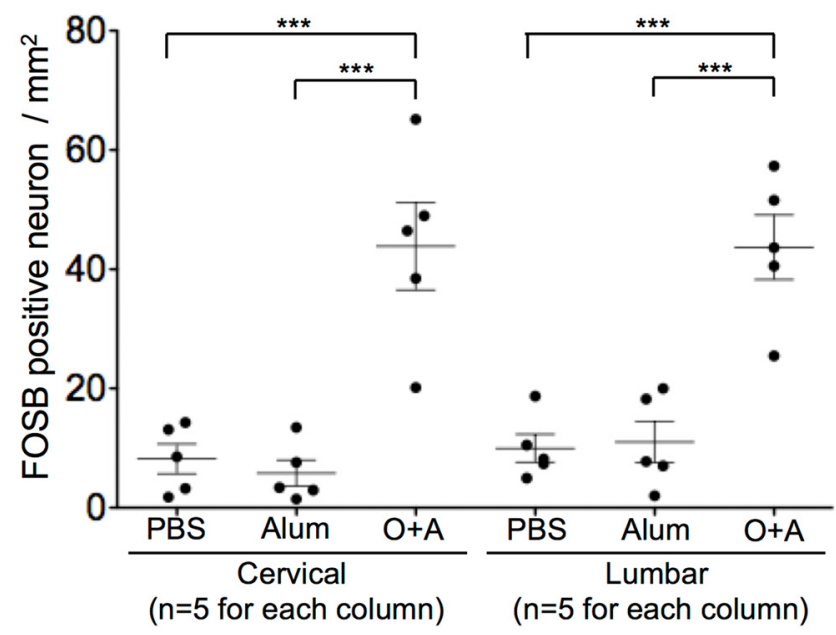

Figure 8. Tactile allodynia with activation of dorsal horn neuron in atopy model mice. Tactile allodynia as determined by von Frey filament test. $A$, Tactile allodynia in bronchial asthma model mice. Reaction rates of PBS-, Alum-, and $0+A$-pretreated mice with different stimulation strength of von Frey filaments. Bars filled with different patterns represent different pretreatments before inhalation of OVA. $n=5$ for each group. $\boldsymbol{B}$, Tactile allodynia is also evident in atopic diathesis mice without inhalation of OVA (0+A group). $n=4$ for each group. $\boldsymbol{C}$, Dorsal horn sensory neurons were activated with increased number of FOSB-positive cells only in the bronchial asthma model. $\boldsymbol{D}$, Quantitative analysis of FOSB-positive cells in the dorsal horns of bronchial asthma model mice. ${ }^{* *} p<00.01$ (Tukey's post test after one-way ANOVA). ${ }^{* * *} p<0.001$ (Tukey's post test after one-way ANOVA).

\section{Results}

Glial inflammation occurs in the spinal cord of atopy model mice C57BL/6 mice received intraperitoneal injection of OVA and Alum on days 0, 7, and 14 of the experiment, for induction of atopic diathesis, followed by direct nasal aspiration of OVA solution (O+A group) (Nials and Uddin, 2008). These mice showed

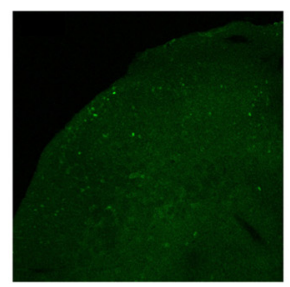

B
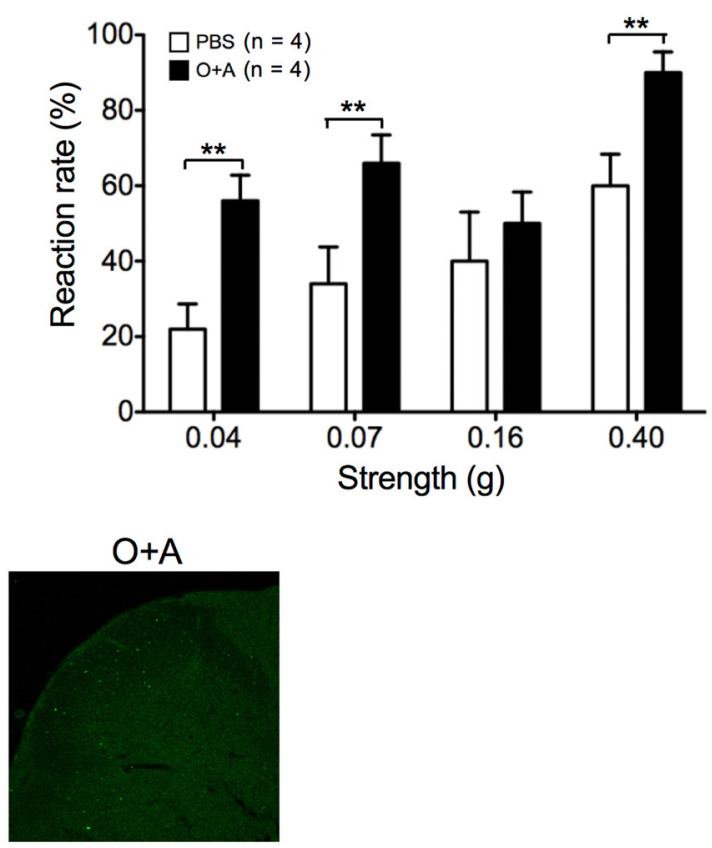

robust infiltration of inflammatory cells, including numerous eosinophil cationic protein-positive eosinophils in the peribronchial and perivascular areas, and mucus overproduction and goblet cell hyperplasia. The PBS group and the Alum group mice did not have eosinophil infiltration, despite OVA inhalation (Fig. $1 A, B)$. In mice with atopic dermatitis induced by direct OVA 
A
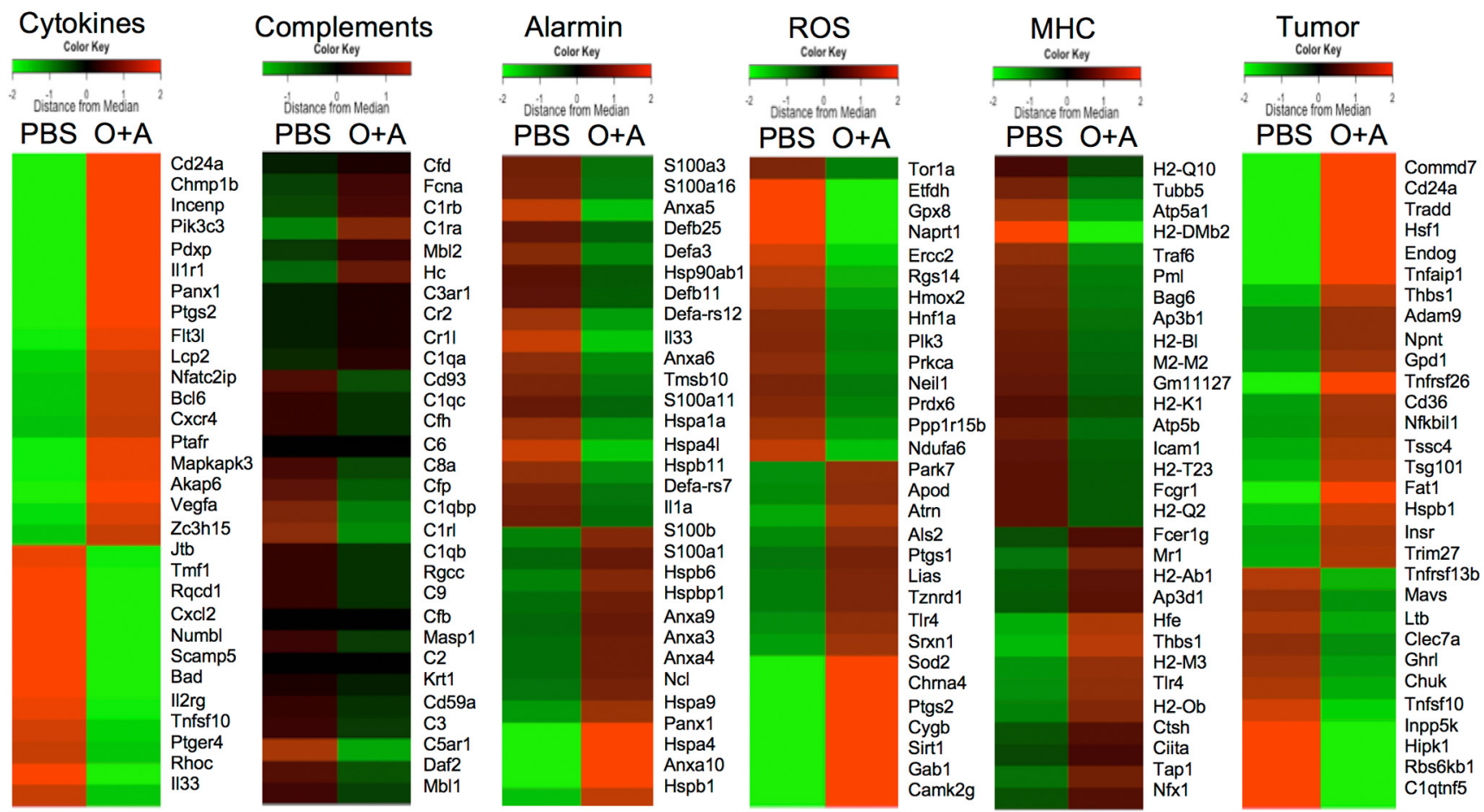

B
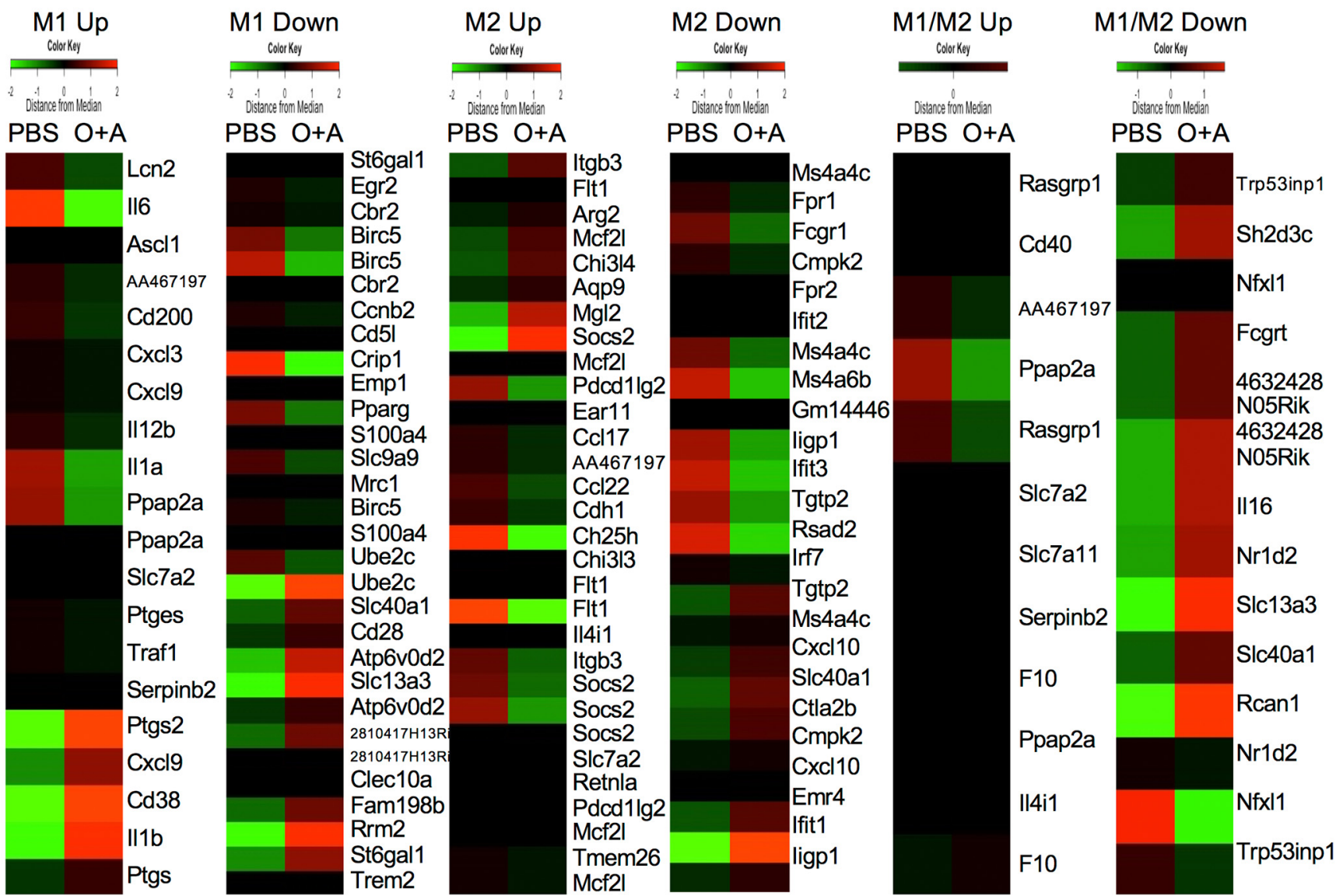

Figure 9. Alterations in gene expression patterns of microglia in atopy model mice. RNA assay results of microglia isolated from spinal cords of mice with and without atopic diathesis. $A$, Cluster analysis of gene expression array that are classified into six common pathways: cytokines, complement, alarmin, reactive oxygen species, major histocompatibility complex antigens, and tumor-related gene. $\boldsymbol{B}$, Cluster analysis of gene expression array according to the macrophage-activation phenotype-related genes. M1 and M2 correspond to the classical (proinflammatory) and alternative (immunoregulatory) phenotypes, respectively. Color key on each column represents Z score for each gene. 
Table 2. Five of the most upregulated genes encoding receptors in microglia

\begin{tabular}{llll}
\hline Gene symbol & Description & $\begin{array}{l}\text { Compared } \\
\text { Zscore } \\
(>2.00)\end{array}$ & $\begin{array}{l}\text { Compared ratio } \\
\text { (control vs atopic } \\
\text { diathesis model mice) }\end{array}$ \\
\hline Ednrb & Ednrb, transcript variant 1 & 2.38 & 78.13 \\
Acvr1b & Activin A receptor, Type 1B & 2.41 & 28.14 \\
Fcgr4 & Fc receptor, IgG, low-affinity IV (Fcgr4) & 2.64 & 2.44 \\
Ifngr1 & Interferon gamma receptor 1 (Ifngr1) & 2.52 & 2.34 \\
Ifngr2 & Interferon gamma receptor 2 (Ifngr2) & 2.32 & 2.19 \\
\hline
\end{tabular}

application on tape-stripped skin (Spergel et al., 1998), marked infiltration of eosinophil cationic protein-positive eosinophils with hypertrophied epidermis was observed, but not in mice injected with PBS instead of OVA (Fig. 1C,D).

Mice with asthma, atopic dermatitis, and atopic diathesis alone showed greater activation of spinal microglia than mice without atopy. In the lumbar spinal cord of mice with bronchial asthma (O+A group), the number of microglia was increased (PBS vs $\mathrm{O}+\mathrm{A}, p=0.0005$; Alum vs $\mathrm{O}+\mathrm{A}, p=0.0026$ ) and ramification was reduced ( $\mathrm{PBS}$ vs $\mathrm{O}+\mathrm{A}, p=0.0102$; Alum vs $\mathrm{O}+\mathrm{A}, p=0.0242$ ) compared with those in the PBS and Alum groups (Fig. 2). No difference was found between the PBS and Alum groups. Such microglial activation was more evident in the cervical cord than the lumbar cord in mice with asthma, whereas in mice with atopic dermatitis it was more evident in the thoracic cord than in the lumbar cord (Fig. $3 A-D$ ), suggesting that microglial activation was more pronounced at the spinal cord levels where allergic airway and skin tissues are innervated (Atoji et al., 2005). However, similar glial activation was also observed in the spinal cord of mice with atopic diathesis alone without overt allergic manifestations (Fig. $3 E, F$ ). On the axial plane, microglial activation was seen preferentially in the posterior horns and columns (Fig. 3G,H). Using Ccr2 ${ }^{\mathrm{rfp} /+} \mathrm{Cx} 3 \mathrm{cr}^{\mathrm{gfp} /+}$ mice (Yamasaki et al., 2014), we confirmed the lack of infiltration of peripheral blood-borne macrophages into the spinal cord of mice with asthma (Fig. 4).

Astroglia were also activated and increased in number in the $\mathrm{O}+\mathrm{A}$ group compared with the PBS and Alum groups, as determined by GFAP and $\mathrm{S} 100 \beta$ immunostaining (PBS vs $\mathrm{O}+\mathrm{A}, p=$ 0.0008; Alum vs $\mathrm{O}+\mathrm{A}, p=0.0055$ ) (Fig. 5). This was observed throughout the spinal cord, regardless of the sites of allergic inflammation (Fig. 6A-D), including both anterior and posterior regions (Fig. 6E,F). Additionally, endothelial cells were activated with increased expression of intercellular adhesion molecule- 1 with extravasation of serum albumin, suggesting impairment of the bloodbrain barrier (BBB) (Fig. 7).

\section{Atopy model mice show severe tactile allodynia}

We then tested tactile allodynia by applying calibrated von Frey filaments on the mid-plantar hindpaw (Chaplan et al., 1994). The $\mathrm{O}+\mathrm{A}$ group showed significantly higher reaction rates than did the PBS and Alum groups (two-way ANOVA; $p=0.0134$ ) (Fig. $8 A$ ). A Bonferroni post hoc test also revealed significantly higher reaction rates in the $\mathrm{O}+\mathrm{A}$ group by each stimulation strength than the PBS and Alum groups $(p<0.001)$, suggesting development of tactile allodynia in mice with asthma. Tactile allodynia was also seen to a lesser extent in mice with atopic diathesis alone without OVA aspiration, as shown by a significantly heightened response when stimulated with $0.04,0.07$, and $0.40 \mathrm{~g}$ filaments $(p<0.01)$ (Fig. $8 B$ ). In the dorsal horn of bronchial asthma model mice, expression of FBJ murine osteosarcoma viral oncogene homolog B (FOSB), a neuronal activation marker for sen- sory neurons (Cruz et al., 2013), was significantly increased compared with the other controls (Fig. 8C,D).

\section{Microglia in atopy mice exhibit dysregulated gene expression profiles}

To determine the genes associated with glial activation, we performed an RNA array assay of microglial cells isolated from the spinal cord of mice with and without atopic diathesis. Among the 39,430 genes screened, 807 genes were dysregulated. These gene array assay results were uploaded to the gene expression omnibus repository (accession number is GSE68202) in the National Center for Biotechnology Information homepage (http://www.ncbi. nlm.nih.gov/geo/query/acc.cgi?acc=GSE68202). The RNA array assay of microglia revealed activations of several pathways, including ubiquitin-mediated proteolysis $(p=0.00076)$, cell cycle $(p=0.015)$, ErbB signaling pathway $(p=0.015)$, and endocytosis $(p=0.018)$. There were apparent differences between the expression levels of each subset of genes in microglia from mice with and without atopic diathesis (Fig. 9A). Among them, cytokine and tumor-related genes showed the most significant dysregulation. These data indicated proinflammatory and proliferating characteristics of microglia in atopic diathesis. Next, we analyzed genes that are known to be dysregulated in classically activated macrophages (M1 phenotype) and alternatively activated macrophages (M2 phenotype) (Jablonski et al., 2015). Among M1-related genes, CD38, which was recently discovered as a novel marker for M1 macrophages, was significantly upregulated in atopic diathesis model mice $(Z$ score $=2.86$, fold increase: 186.8). Reciprocally, FMS-like tyrosine kinase 1 (Flt1), which is known to be increased in M2-related macrophage, was significantly downregulated $(Z$ score $=-2.368$, fold increase: 0.015) (Fig. 9B). These results clearly indicate a tendency for microglia to deviate to a proinflammatory (M1 like) phenotype in atopic diathesis model mice.

\section{Endothelin-1 and its receptor are upregulated in atopy model mice}

We next focused on gene clusters that encode cell surface receptors and found that Ednrb gene expressions were strikingly upregulated $(Z$ score $=2.38$, fold increase: 78.13 ) (Table 2). Immunohistochemical analysis showed EDNRB expression was enhanced in microglia, and more prominently in astroglia of mice with asthma, compared with mice without asthma (Fig. $10 A, B)$. Western blot analysis using whole spinal cords also demonstrated elevated levels of EDNRB in asthma model mice (Fig. $10 C, D)$. Immunohistochemical staining of ET-1 in the lung tissues revealed marked upregulation of ET-1 in alveolar epithelial cells and infiltrated inflammatory cells in mice with asthma, but not in those without asthma (Fig. 10E). ET-1 expression was also enhanced in atopic dermatitis skin tissues (Fig. 10F). Correspondingly, in mice with asthma, serum levels of ET-1, an EDNRB ligand, were significantly elevated in comparison with mice without asthma ( $p=0.0238$ ) (Fig. $10 G)$, despite the very short half-life of ET-1 (7 min) (Rubin and Levin, 1994). By contrast, another main receptor for ET-1, endothelin receptor type A (EDNRA), was not detected in the spinal cord of bronchial asthma model mice, including microglia and astroglia (Fig. $10 H, I)$. Spinal cord neurons did not express either EDNRA or EDNRB (Fig. 10J). Although interferon regulatory factor-8 (IRF8) (Masuda et al., 2012) and satellite cells (Xu et al., 2013) are thought to be involved in PNI-related allodynia, we did not observe positive staining of IRF8 in microglia (Fig. 11A), or satellite cell activation in DRG (Fig. 11B), of mice with asthma. Although 

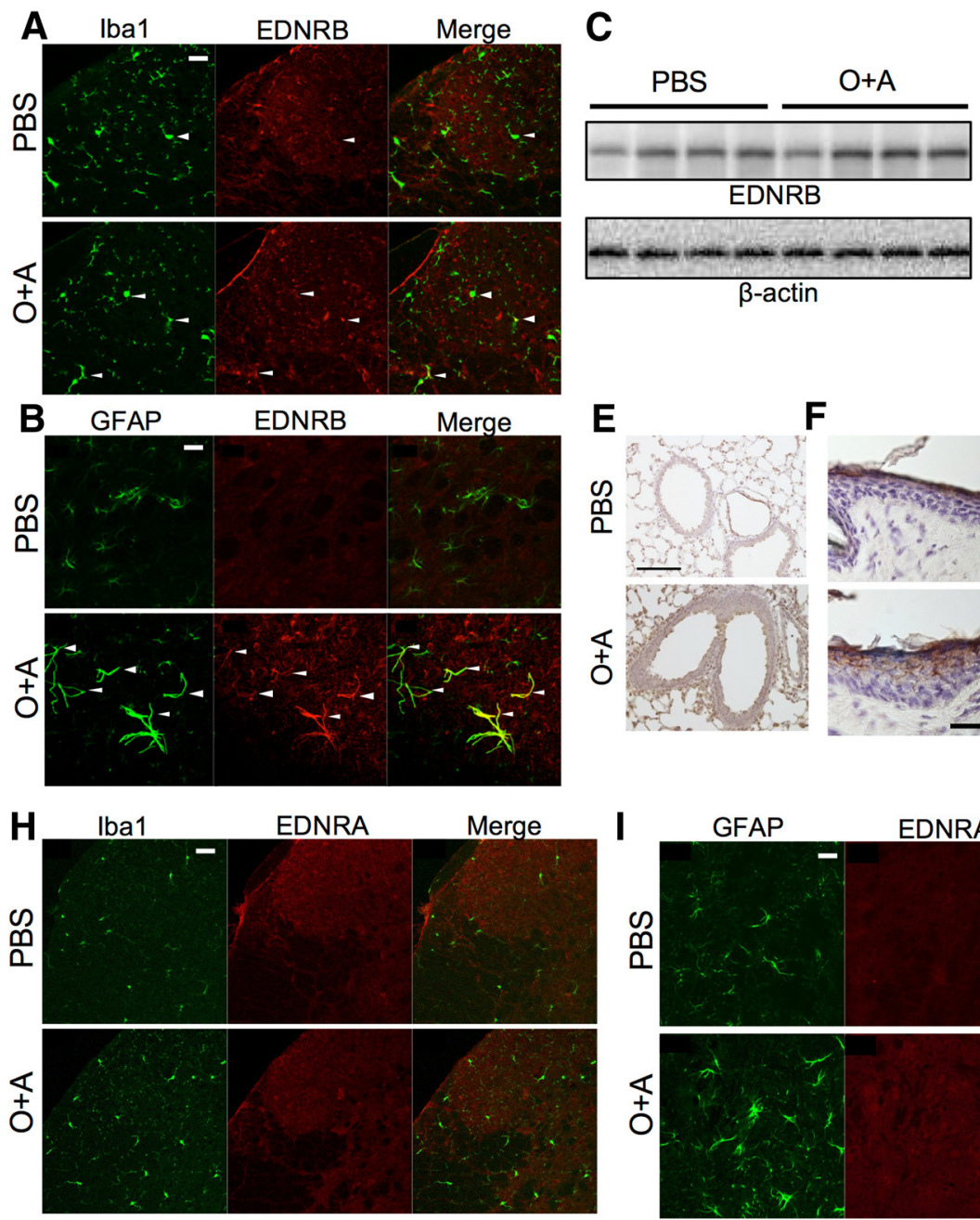

$\mathbf{F}$
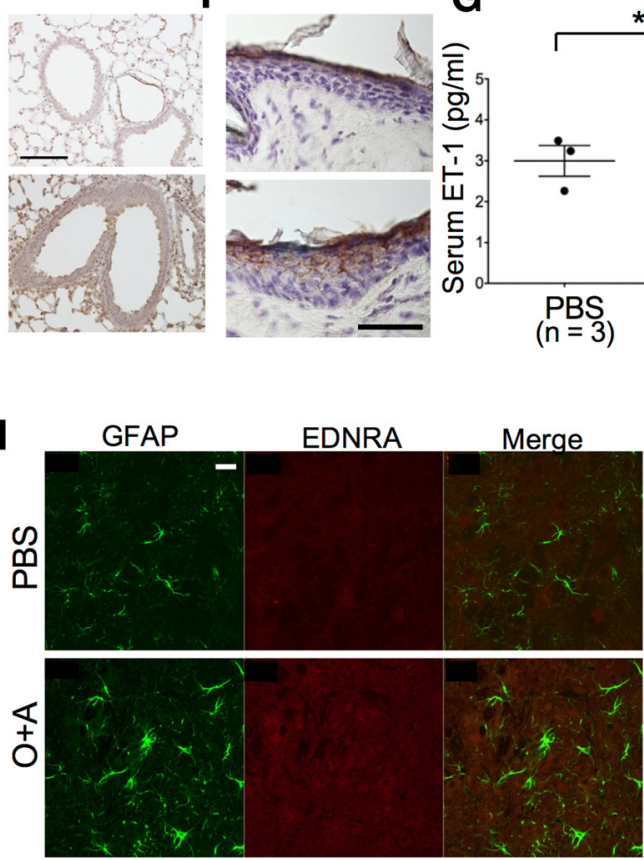

D

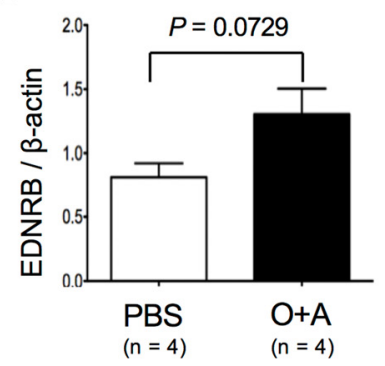

G

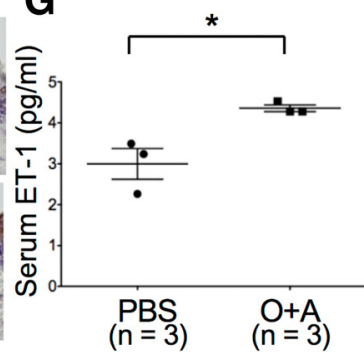

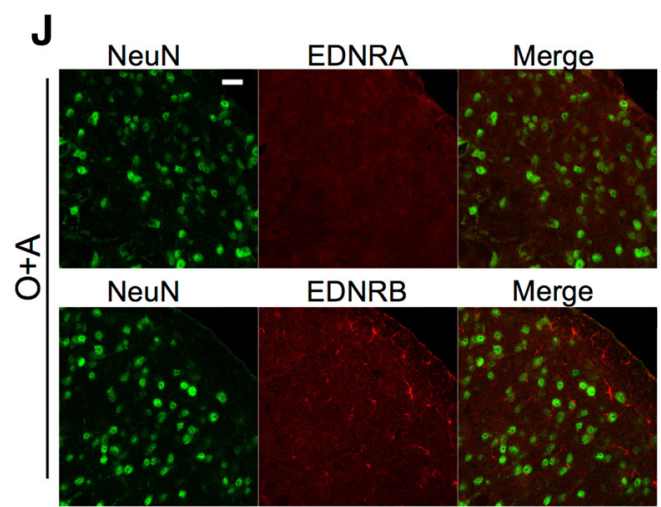

Figure 10. Upregulation of ET-1 and EDNRB in atopy model mice. $A$, Double immunostaining with anti-lba1 and anti-EDNRB antibodies of the lumbar spinal cord specimens from PBS-pretreated and $0+$ A-pretreated mice. $\boldsymbol{B}$, Double immunostaining with anti-GFAP and anti-EDNRB antibodies of the lumbar spinal cord specimens from PBS-pretreated and $0+$ A-pretreated mice. $\boldsymbol{A}$, Arrowheads indicate coexpression of EDNRB and Iba1 on microglia. $\boldsymbol{B}$, Arrowheads indicate coexpression of EDNRB and GFAP. EDNRB expression is more prominent in astroglia than in microglia in the $0+$ A group. Scale bars, $100 \mu \mathrm{m}$. C, Immunoblotting of EDNRB using the spinal cord from PBS-pretreated and $0+A$-pretreated mice. $D$, Relative density of EDNRB immunoblots using the spinal cord from PBS-pretreated and $0+A$-pretreated mice. E, Immunostaining of ET-1 in the lung from PBS-pretreated and $0+$ A-pretreated bronchial asthma model mice. ET-1 immunostaining (brown) is markedly upregulated in the $0+$ A group. Scale bar, $50 \mu \mathrm{m}$. $\boldsymbol{F}$, Immunostaining of ET-1 in the skin from PBS-swabbed and OVA-swabbed atopic dermatitis model mice. ET-1 immunostaining (brown) is enhanced in the epidermis of OVA-swabbed mice compared with PBS-swabbed mice. Scale bar, $50 \mu \mathrm{m}$. G, Serum ET-1 level is increased in the $0+$ A group compared with the PBS group. $\boldsymbol{H}$, Double immunostaining with anti-lba1 and anti-EDNRA antibodies of the lumbar spinal cord specimens from PBS-pretreated and $0+$ A-pretreated mice. $I$, Double immunostaining with anti-GFAP and anti-EDNRB antibodies of the lumbar spinal cord specimens from PBS-pretreated and 0+A-pretreated mice. J, Double immunostaining with anti-neuronal nuclei (NeuN) and anti-EDNRA or anti-EDNRB antibodies of the lumbar spinal cord specimens from $0+$ A-pretreated mice. Scale bars: $\boldsymbol{H}-\boldsymbol{J}, 100 \mu \mathrm{m} .{ }^{*} p<0.05$ (Tukey's post test after one-way ANOVA). 
the microglia phenotype deviated to M1, there was neither demyelination nor axonal degeneration (Fig. 11C,D).

\section{Atopy-related glial activation and allodynia are prevented by an EDNRB antagonist}

We then studied the effects of a selective EDNRB antagonist, BQ-788 (Lo et al., 2005), on glial activation and allodynia in mice with atopy (Fig. 12A). BQ-788 did not alter mucus overproduction and goblet cell hyperplasia and eosinophil infiltration in the lung (Fig. 12B). Surprisingly, BQ-788 not only abolished activation of microglia, astroglia, and dorsal horn sensory neurons but also efficiently resolved allodynia in mice with asthma, whereas serum IgE levels remained unaltered, and activation of endothelial cells with increased expression of intercellular adhesion molecule-1 and extravasation of serum albumin were unchanged (Figs. $12 \mathrm{C}-\mathrm{H}, 13)$. These results suggest that development of allodynia in atopy model mice is mainly attributable to the ET-1/ EDNRB pathway leading to activation of spinal astroglia and microglia.

\section{Atopic patients with myelitis predominantly presenting neuropathic pain show activation of the \\ ET-1/EDNRB pathway}

A fraction of atopy sufferers possessing susceptibility genes, such as HLA$D R B 1^{\star} 02: 01$ (Sato et al., 2012), are reported to develop myelitis presenting with persistent neuropathic pain. Therefore, we conducted neuropathological examination of spinal cord specimens from an autopsied case of atopic myelitis. We found diffuse activation of microglia and astroglia in the posterior horns of the spinal cord (Fig. 14A), which was accompanied by loss of both myelin and axons, as previously reported in the biopsied spinal cord tissues (Kikuchi et al., 2001; Osoegawa et al., 2003b). In this case, only a few $\mathrm{CD}^{+} \mathrm{T}$ cells and $\mathrm{CD} 68^{+}$macrophages, but not $\mathrm{CD}^{+}{ }^{+} \mathrm{T}$ cells, infiltrated in the spinal cord parenchyma (Fig. 14B), probably reflecting the patient's longstanding corticosteroid therapy. EDNRB expression was markedly upregulated mainly on the astroglial surface (Fig. $14 C, D)$, which is compatible with the findings in our atopy model mice.

Finally, we measured serum ET-1 levels in atopic patients with myelitis presenting neuropathic pain (Isobe et al., 2012) and healthy controls without atopy (Table 3). Compared with healthy controls without atopy and neuropathic pain, serum ET-1 levels were significantly elevated in atopic patients with myelitis and neuropathic pain, although atopic patients with myelitis and neuropathic pain had taken antiallergy drugs more frequently, which could reduce serum ET-1 levels (Fig. 14E; Table 3) (Ziet-
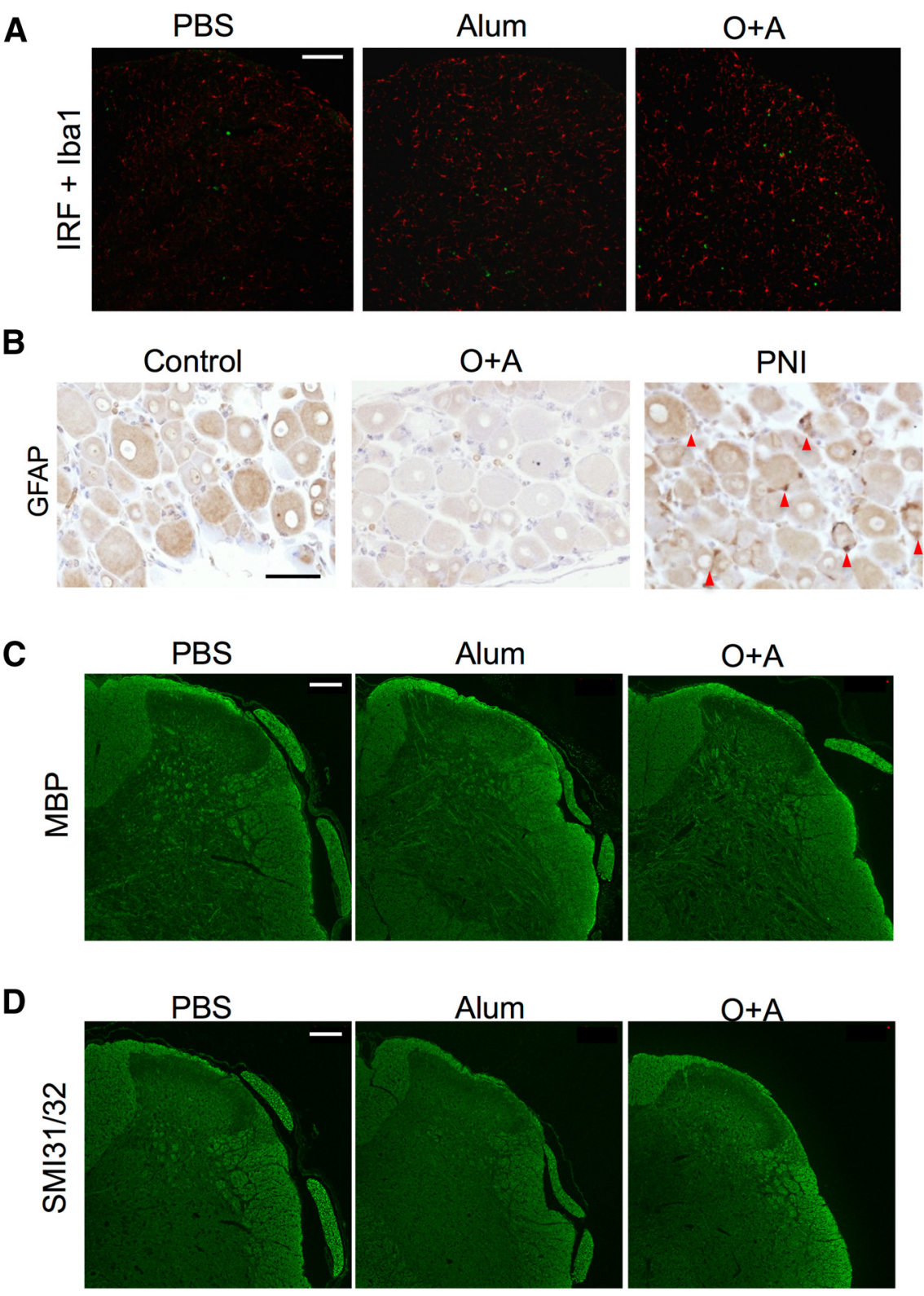

Figure 11. Immunohistochemistry of the lumbar spinal cord from atopy model mice and of the DRG from distinct neuropathic pain model mice. $A$, Immunohistochemistry for IRF8 of the lumbar spinal cord from PBS-pretreated, Alum-pretreated, and $0+A$ cells are activated and positive for GFAP (red arrowheads), whereas activation of satellite glia is not evident in $0+A$ pretreated mice with asthma. Scale bars: $A, B, 50 \mu \mathrm{m}$. C, Immunohistochemistry for myelin basic protein (MBP). $\boldsymbol{D}$, Immunochemistry of SMI31/32. There is neither obvious demyelination nor axonal degeneration. Scale bars: $C, D, 100 \mu \mathrm{m}$.

kowski et al., 2010). These observations suggest a similar mechanism involving the ET-1/EDNRB pathway that, in part, acts in atopic patients with myelitis presenting neuropathic pain.

\section{Discussion}

This study shows that atopic disorders, such as atopic dermatitis and asthma, and even atopic diathesis alone, can induce widespread activation of spinal astroglia and microglia. Activation of spinal microglia was seen predominantly in the posterior horns and columns, and these activated microglia exhibited a dysregulated proinflammatory phenotype. Although endothelial cells were activated and the BBB was compromised in mice with asthma, microglial activation, but not 


\section{A}

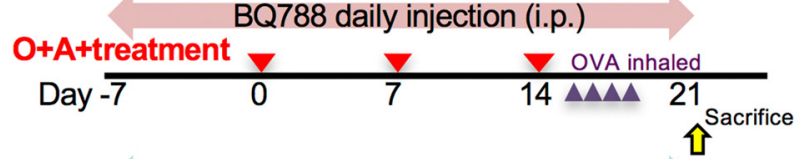

BQ788 daily injection (i.p.)
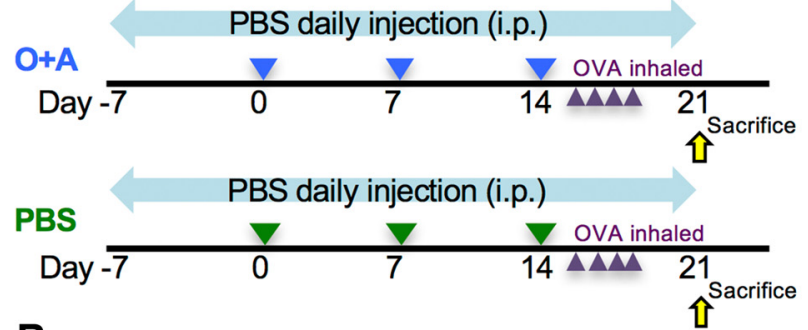

B

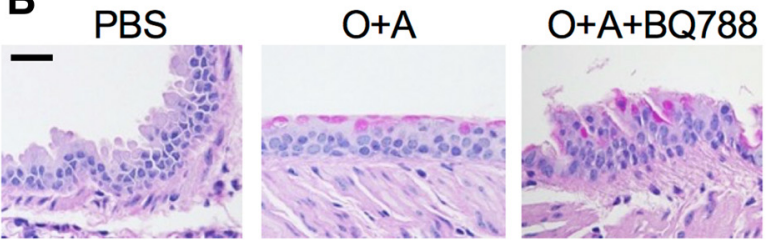

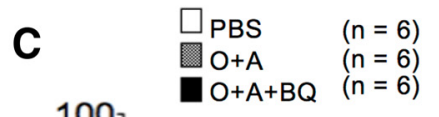

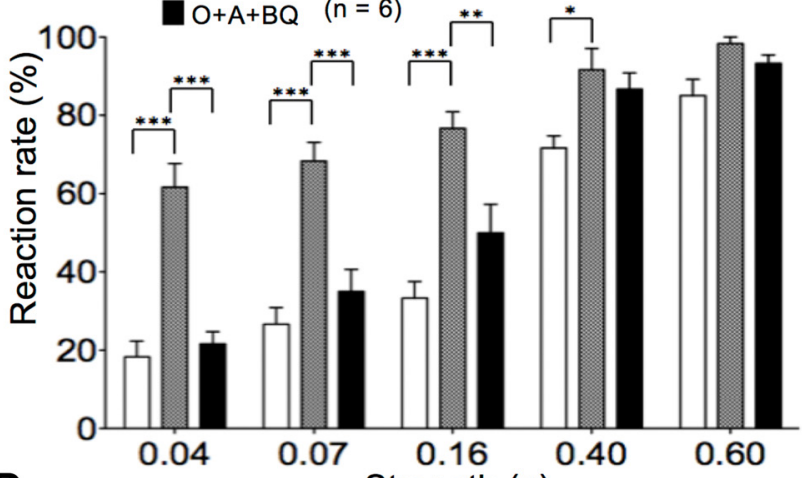

D Strength $(\mathrm{g})$
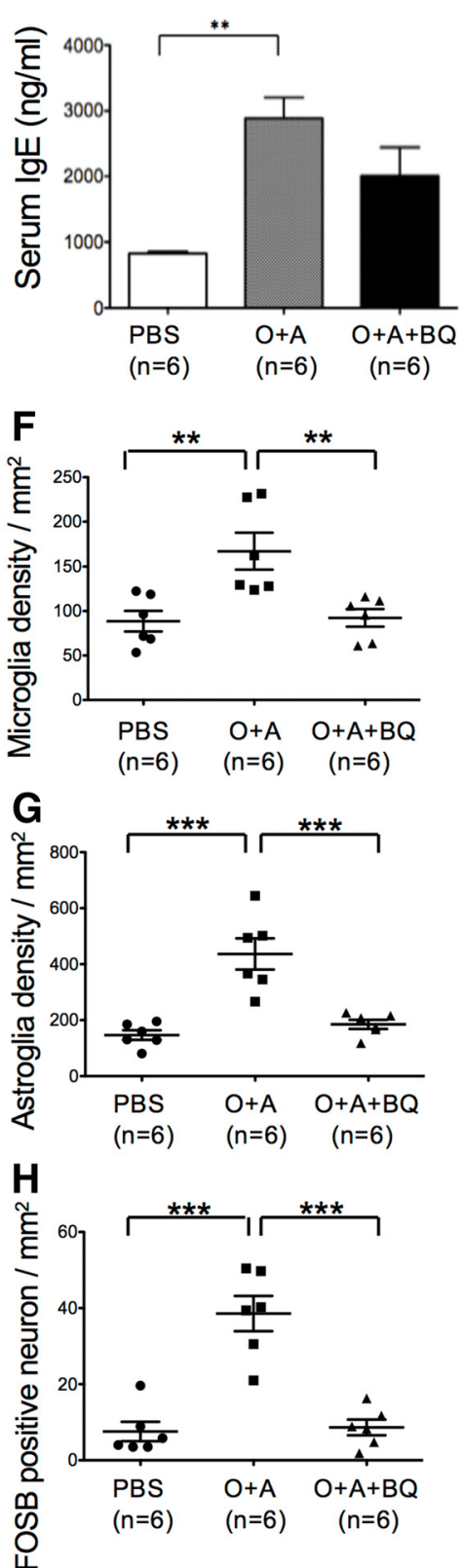

Figure 12. Prevention of glial activation and allodynia in mice with asthma. $A$, Schematic drawing of the preventive therapy protocols to treat glial activation and allodynia in bronchial asthma model mice. Before induction of atopic diathesis, BQ788 $(1 \mu \mathrm{g} / \mathrm{kg} / \mathrm{d})$ was injected intraperitoneally from day 7 until day 19 when mice were killed. $\boldsymbol{B}$, Periodic acid-Schiff staining of the lung shows mucus overproduction and goblet cell hyperplasia in $0+A$-pretreated mice with or without the preventive treatments, indicating successful induction of bronchial asthma. Scale bar, $20 \mu \mathrm{m}$. $C$, Tactile allodynia as determined by von Frey filament test in PBS-pretreated, $0+\mathrm{A}$-pretreated, and $0+\mathrm{A}$ and BQ788 $(0+\mathrm{A}+\mathrm{BQ})$-pretreated mice. There is marked (Figure legend continues.) 
invasion of peripheral blood macrophages, was also supported by the results from the $\mathrm{Ccr} 2^{\mathrm{rfp} /+} \mathrm{Cx} 3 \mathrm{cr} 1^{\mathrm{gfp} /+}$ mice. Intriguingly, glial activation in atopy was accompanied with the emergence of tactile allodynia. Because we initially found no differences in either glial activation or allodynia between the PBS and Alum groups, some of our experiments used the PBS group but not the Alum group as controls. Although careful interpretation is needed for such data, microglial and astroglial activation coinciding with development of allodynia was strikingly consistent in asthma model mice, even compared with the Alum groups. However, neither IRF8 (Tsuda et al., 2003) nor DRG satellite glia (M.H. Chen et al., 2014) appeared contributory, suggesting a distinct cascade from PNI-related allodynia to be operative in atopy-related allodynia.

Recently, it was reported that focal activation of astroglia without microglial activation in the posterior horns innervating the localized atopic dermatitis skin amplified a chronic itch sensation in mice (Shiratori-Hayashi et al., 2015). This differs from our systemic atopy model demonstrating both microglial and astroglial activation, although both findings collectively support a possible link between atopy and spinal glial activation. Given that even in our model microglial activation was more pronounced at the spinal cord levels where allergic airway and skin tissues are innervated, sensory neuronal inputs may also partly contribute to microglial activation. The observation that astrocyte activation had no relation with the sites of allergic inflammation suggests a smaller contribution of local allergyrelated factors to this phenomenon. Importantly, atopic diathesis alone could induce not only glial activation but also allodynia, probably through certain systemic factors. Thus, it is suggested that atopy could persistently exert widespread stimulating effects on not only spinal astroglia but also microglia, leading to activation of the nociceptive system.

In our allergic inflammation model, the ET-1/EDNRB pathway seems to be critical for both glial activation and allodynia. ET-1 is produced by a variety of cells, such as endothelial cells, vascular smooth muscle cells, leukocytes, mast cells, macrophages, and even neurons (Smith et al., 2014). Both EDNRA and EDNRB are involved in neuropathic and inflammatory pain, although the interaction between the endothelin system and the nociceptive system is highly complex (Smith et al., 2014).

$\leftarrow$

(Figure legend continued.) amelioration of allodynia by $\mathrm{BQ788}$ treatment in mice with asthma. $\boldsymbol{D}$, Serum IgE levels in PBS-pretreated, $0+A$-pretreated, $0+A+B Q$-pretreated mice. $E$, Immunostaining with anti-lba1 antibody, anti-S100 $\beta$ antibody, and anti-F0SB antibody of the lumbar spinal cord specimens from PBS-pretreated, $0+A$-pretreated, and $0+A+B Q-$ pretreated mice. Scale bar, $100 \mu \mathrm{m}$. $\boldsymbol{F}$, Microglial cell density. $\mathbf{G}$, Astroglial cell density. $\boldsymbol{H}$, FOSB-positive neuron density. ${ }^{*} p<0.05$ (Tukey's post test after one-way ANOVA). ${ }^{* *} p<0.01$ (Tukey's post test after one-way ANOVA). ${ }^{* *} p<0.001$ (Tukey's post test after one-way ANOVA).
EDNRA is expressed on the peripheral nerve endings of the nociceptors, nerve axons, and the nociceptor cell bodies (Pomonis et al., 2001). EDNRB is found on endothelial cells, macrophages, keratinocytes, and smooth muscle cells (Smith et al., 2014). Peripherally administered ET-1 increases nociceptive behavior in humans and rodents via EDNRA receptors on sensory neurons, whereas administration of ET-1 directly into the CNS is often antinociceptive, where ET-1 activates a descending inhibitory pathway to the spinal cord, possibly through the release of endogenous opioids (Smith et al., 2014). In a chronic arthritis model, a selective EDNRB blocker was reported to enhance nociception (Piovezan et al., 2004), whereas in a model of trigeminal neuralgia induced by trigeminal injury, mechanical allodynia was reduced by EDNRB blockade (Chichorro et al., 2006). In our study, mechanical hyperalgesia was abrogated by selective blockade of EDNRB, which also abolished glial and neuronal activation. As neuronal expression of either EDNRA or EDNRB was hardly detectable in our atopy mice, it is less likely that the EDNRB antagonist primarily acted on neurons. Instead, these findings suggest the importance of microglia and astroglia in the emergence of allergic inflammation-related neuropathic pain.

As accumulating evidence suggests that ET-1 attenuates BBB integrity (Matsuo et al., 2001; Didier et al., 2003; Leung et al., 2009), ET-1 produced by inflamed allergic tissues may increase $\mathrm{BBB}$ permeability and activate EDNRB-harboring microglia and astroglia through compromised $\mathrm{BBB}$ in atopic inflammatory conditions. In our study, selective EDNRB blockade by BQ788 could not block either endothelial cell activation or albumin leakage, which can be explained by the fact that ET-1-induced endothelial activation and BBB damage are mediated by EDNRA, not EDNRB (Matsuo et al., 2001). It is also possible that peripheral 
A

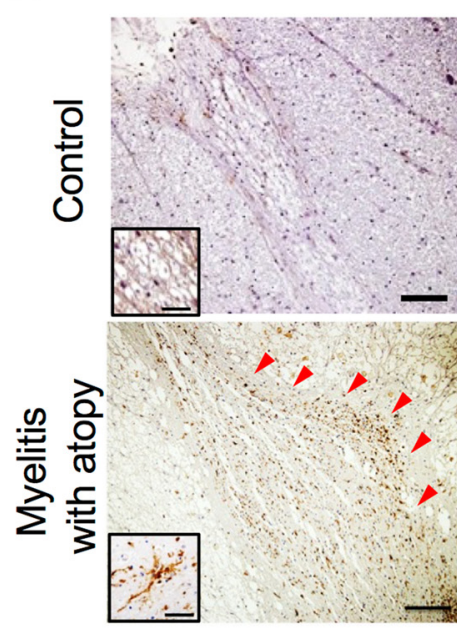

B

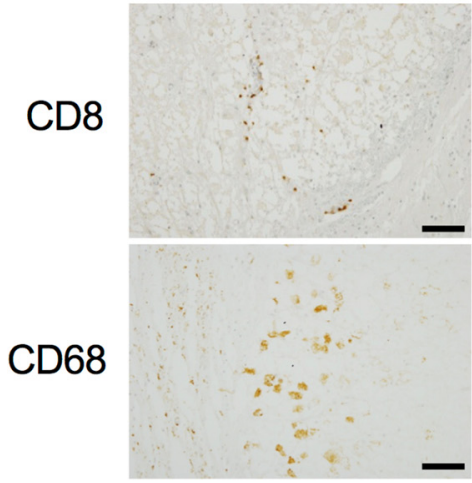

lba1

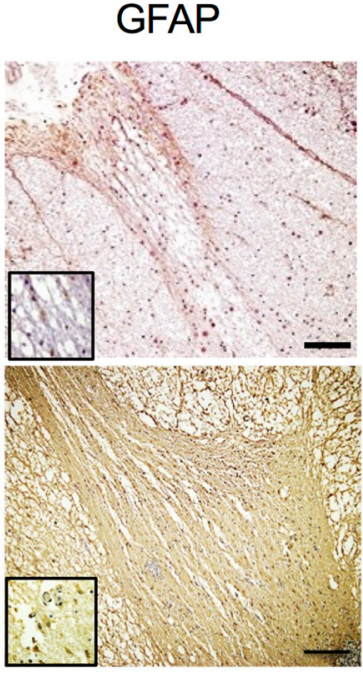

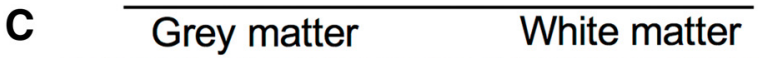

C
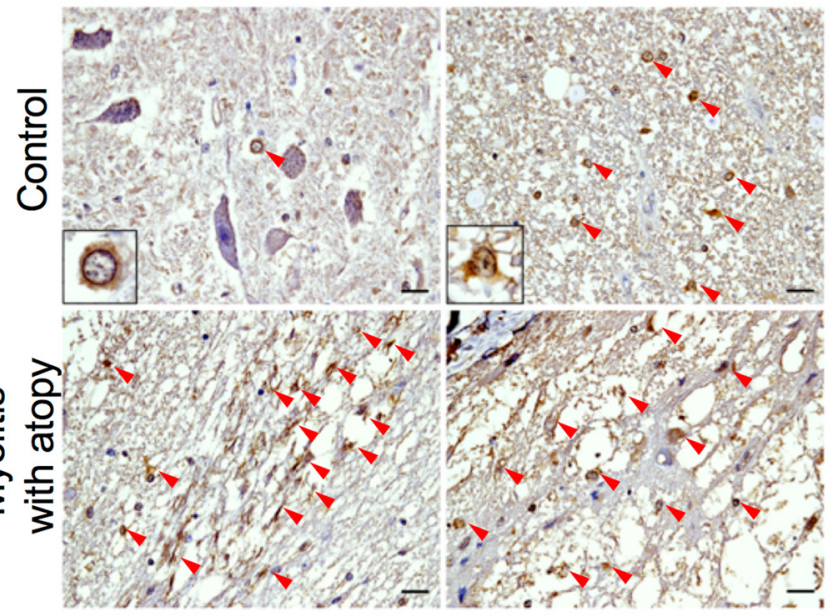

D
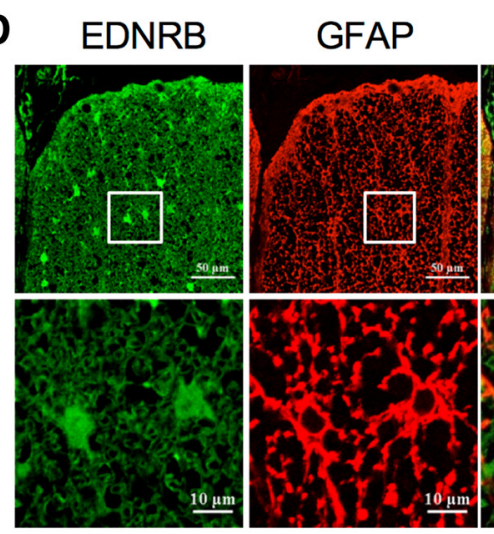

Merged

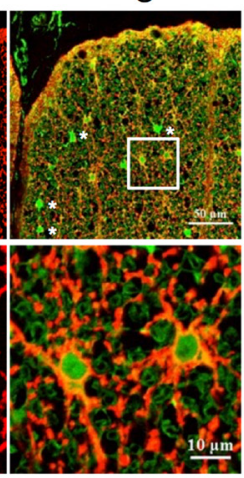

E

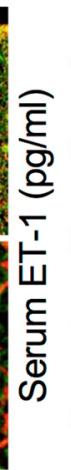

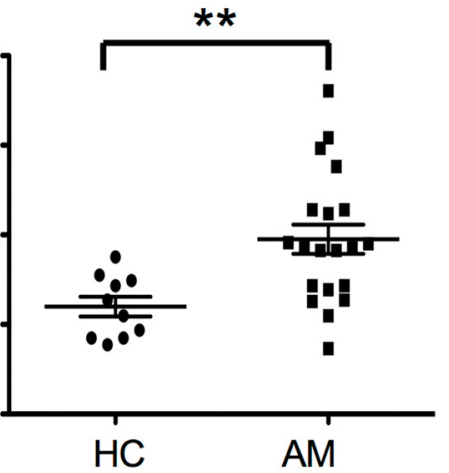

Figure 14. Glial activation and increased serum ET-1 levels in atopic myelitis. $\boldsymbol{A}-\boldsymbol{D}$, Glial activation in autopsied spinal cord specimens from an atopic patient with myelitis and neuropathic pain who fulfilled the established diagnostic criteria for atopic myelitis with high specificity and sensitivity (both $>90 \%$ ) (Isobe et al., 2012). $A$, Immunohistochemical analysis for glial inflammation in the cervical spinal cord from the autopsied atopic patient with myelitis and neuropathic pain. Control samples were from a patient who died of septic shock without any neurological signs and atopy. There is a robust increase in astroglia and microglia in the cervical spinal cord from the atopic patient with myelitis and neuropathic pain. Scale bars, $200 \mu \mathrm{m}$. Scale bars: inset, $50 \mu \mathrm{m}$. $\boldsymbol{B}$, Immunostaining of CD8 and CD68 in the spinal cord tissues. A few CD8 ${ }^{+} \mathrm{T}$ cells and CD68 ${ }^{+}$macrophages have infiltrated into the spinal cord parenchyma. Scale bars, $100 \mu \mathrm{m} . \mathrm{C}$, Immunostaining of EDNRB in the spinal cord tissues. EDNRB is expressed in the spinal cord astroglia in the control tissue, whereas it is markedly upregulated in astroglia in the tissue from the atopic patient with myelitis and neuropathic pain. Scale bars, $20 \mu \mathrm{m}$. D, Double immunofluorescent staining of the cervical spinal cord samples from the atopic patient with myelitis and neuropathic pain. Almost all of the EDNRB-positive cells merge with GFAP-positive astroglia, although some GFAP-negative cells (white asterisks) are also evident. Scale bars: top row, $50 \mu \mathrm{m}$; bottom row, $10 \mu \mathrm{m}$. E, Serum ET-1 levels in human samples, including healthy controls without atopic disorders and patients with atopic myelitis. Significant increases in serum ET-1 levels are observed in atopic myelitis patients compared with healthy controls without atopic disorders $(p=0.0052) .{ }^{* *} p<0.01$ (Mann-Whitney $U$ test). HC, Healthy controls; AM, atopic myelitis.

Table 3. Demographic features of the subjects ${ }^{a}$

\begin{tabular}{lll}
\hline & HC & AM \\
\hline$n$ & 10 & 20 \\
Age, yr, mean (range) & $38.9(24-68)$ & $41.2(20-67)$ \\
Sex ratio (male: female) & $b: 2$ & $4: 16$ \\
Atopic diathesis, $n$ (\%) $_{\text {Antiallergic drug (including PSL) } n(\%)}$ & $0(0 \%)$ & $20(100.0 \%)$ \\
Serum ET-1, pg/ml, mean \pm SD & $0(0 \%)$ & $15(75.0 \%)$ \\
\hline
\end{tabular}

${ }^{a} \mathrm{HC}$, Healthy control; $\mathrm{AM}$, atopic myelitis.

${ }^{b}$ Although the sex ratio was different between the two groups, differences of ET-1 levels by sex were not found in our and others' studies (Tsybikov et al. 2015).

blood proinflammatory cytokines released from atopic inflammatory tissues may contribute in part to damage of BBB integrity (Chesné et al., 2014; Waisman et al., 2015). Thus, it is conceivable that BQ788 directly inhibits glial cell activation entering through the dampened BBB in our atopy model mice.

We showed that ET-1 is produced in lung and skin tissues in atopic mice, which is consistent with augmented ET-1 expression in the epidermis of atopic dermatitis patients (Aktar et al., 2015) and the bronchial epithelium of asthma patients (Pégorier et al., 2007). We also found that serum ET-1 was significantly elevated in human patients who fulfilled the established diagnostic criteria for atopic myelitis, yet most of them were receiving antiallergy drugs that can potentially decrease ET-1 levels (Zietkowski et al., 2010). This is in accordance with a recent report that peripheral blood ET-1 was increased in patients with atopic dermatitis on exacerbation (Tsybikov et al., 2015) because atopic myelitis develops and recurs on or immediately after exacerbation of atopic diseases (Kira et al., 1997, 1998; Osoegawa et al., 2003a; Murai et al., 2004; Isobe et al., 2009). Given that ET-1 has a half-life of 7 min (Rubin and Levin, 1994), a significant increase of ET-1 in patients with atopic myelitis may suggest persistent production of ET-1 during exacerbation of atopic myelitis. Interestingly, the first autopsy case with atopic myelitis demonstrated activation of both microglia and astroglia with marked EDNRB upregulation in the spinal cord, especially in the posterior horns, which is in accordance with the pathological findings in our atopy model 
mice. This suggests that a similar mechanism inducing glial activation and neuropathic pain via the ET-1/EDNRB pathway could be, at least in part, operative in humans.

ET-1 is a potent pruritogen in humans and reported to be increased in the skin of patients with prurigo nodularis (KidoNakahara et al., 2014). Furthermore, patients with atopic dermatitis demonstrate lower electrical current perception threshold than healthy individuals (Kobayashi et al., 2003). It is possible that ET-1 plays an important role in augmenting not only pruritus but also pain sensation, contributing to increased sensitivity against sensory stimuli in atopic patients. Plasma exchange can efficaciously relieve neurologic symptoms, including neuropathic pain and exacerbation of atopic diseases, such as atopic dermatitis and atopic asthma in patients with atopic myelitis (Osoegawa et al., 2003a; Murai et al., 2004; Isobe et al., 2009). This supports the notion that humoral factor(s), including ET-1, may worsen atopic myelitis together with atopic disorders.

The biopsied spinal cord samples from patients with atopic myelitis were shown to have active inflammation with infiltration of peripheral immune cells, including $\mathrm{T}$ cells, B cells, macrophages, and varying degrees of eosinophils (Kikuchi et al., 2001; Osoegawa et al., 2003b). CD4 ${ }^{+}$T cells infiltrate perivascularly, whereas $\mathrm{CD} 8{ }^{+} \mathrm{T}$ cells invade into the parenchyma in atopic myelitis (Kikuchi et al., 2001; Osoegawa et al., 2003b). By contrast, we did not observe any infiltration of peripheral immune cells into the spinal cords in our atopy model mice, yet glial activation was commonly seen in both the atopy model mice and human atopic myelitis patients. One of the suggested reasons might be the difference in disease duration; the average age at onset for atopic myelitis is in the 30s, decades behind the onset of atopic diseases in the body (Osoegawa et al., 2003a; Isobe et al., 2009). Thus, long and repeated exposure of ET-1, together with a persistently dampened $\mathrm{BBB}$, may induce inflammatory cell infiltration in human patients. Alternatively, autoantibodies or autoimmune cells targeting the CNS tissues may be required to produce peripheral immune cell infiltration because plasma exchanges are effective for atopic myelitis (Murai et al., 2004) and experimental autoimmune encephalomyelitis is worsened by ET-1 (Guo et al., 2014). A search for autoimmunity in patients with atopic myelitis is now underway. Further neuropathological studies using more samples from similar patients with atopy and myelitis are required. Elucidation of the downstream cascade from ET-1/EDNRB-mediated glial activation toward exaggerated nociceptor activation in our atopy model is also needed in future studies.

In conclusion, our study reveals a novel mechanism whereby allergic inflammation causes overactivation of the nociceptive system through widespread microglial and astroglial activation in the spinal cord. The observation that common allergic inflammation could induce widespread activation of microglia and astroglia may provide some clues to the mechanisms of neuropsychiatric comorbidity with atopy, as well as neuropathic pain of ill-defined cause, in which activated microglia and astroglia are hypothesized to play critical roles (Tsuda et al., 2003; Laurence and Fatemi, 2005; Morgan et al., 2010). Our findings suggest that the ET-1/EDNRB pathway might be a novel therapeutic target in atopy-related CNS manifestations.

\section{References}

Ainiding G, Yamashita K, Torii T, Furuta K, Isobe N, Matsushita T, Masaki K, Matsumoto S, Kira J (2012) Clinical disability progression and platelet GP IIb/IIIa values in patients with atopic myelitis. J Neuroimmunol 246: 108-112. CrossRef Medline
Aktar MK, Kido-Nakahara M, Furue M, Nakahara T (2015) Mutual upregulation of endothelin-1 and IL-25 in atopic dermatitis. Allergy 70:846854. CrossRef Medline

Atoji Y, Kusindarta DL, Hamazaki N, Kaneko A (2005) Innervation of the rat trachea by bilateral cholinergic projections from the nucleus ambiguus and direct motor fibers from the cervical spinal cord: a retrograde and anterograde tracer study. Brain Res 1031:90-100. CrossRef Medline

Cardona AE, Huang D, Sasse ME, Ransohoff RM (2006) Isolation of murine microglial cells for RNA analysis or flow cytometry. Nat Protoc 1:19471951. CrossRef Medline

Chaplan SR, Bach FW, Pogrel JW, Chung JM, Yaksh TL (1994) Quantitative assessment of tactile allodynia in the rat paw. J Neurosci Methods 53:5563. CrossRef Medline

Chen G, Park CK, Xie RG, Berta T, Nedergaard M, Ji RR (2014) Connexin-43 induces chemokine release from spinal cord astrocytes to maintain late-phase neuropathic pain in mice. Brain 137:2193-2209. CrossRef Medline

Chen MH, Su TP, Chen YS, Hsu JW, Huang KL, Chang WH, Chen TJ, Pan TL, Bai YM (2014) Is atopy in early childhood a risk factor for ADHD and ASD? A longitudinal study. J Psychosom Res 77:316-321. CrossRef Medline

Chesné J, Braza F, Mahay G, Brouard S, Aronica M, Magnan A (2014) IL-17 in severe asthma: where do we stand? Am J Respir Crit Care Med 190: 1094-1101. CrossRef Medline

Chichorro JG, Zampronio AR, Rae GA (2006) Endothelin ET(B) receptor antagonist reduces mechanical allodynia in rats with trigeminal neuropathic pain. Exp Biol Med (Maywood) 231:1136-1140. Medline

Constantinescu CS, Thomas M, Zaman AG (2006) Atopic optic neuritis. Ocul Immunol Inflamm 14:125-127. CrossRef Medline

Cruz FC, Koya E, Guez-Barber DH, Bossert JM, Lupica CR, Shaham Y, Hope BT (2013) New technologies for examining the role of neuronal ensembles in drug addiction and fear. Nat Rev Neurosci 14:743-754. CrossRef Medline

Didier N, Romero IA, Créminon C, Wijkhuisen A, Grassi J, Mabondzo A (2003) Secretion of interleukin-1beta by astrocytes mediates endothelin-1 and tumour necrosis factor-alpha effects on human brain microvascular endothelial cell permeability. J Neurochem 86 : 246-254. CrossRef Medline

Gregoire SM, Mormont E, Laloux P, Godfraind C, Gilliard C (2006) Atopic myelitis: a clinical, biological, radiological and histopathological diagnosis. J Neurol Sci 247:231-235. CrossRef Medline

Guo Y, Chung SK, Siu CW, Kwan SC, Ho PW, Yeung PK, Chan KH (2014) Endothelin-1 overexpression exacerbates experimental allergic encephalomyelitis. J Neuroimmunol 276:64-70. CrossRef Medline

Hopkins IJ (1974) A new syndrome: poliomyelitis-like illness associated with acute asthma in childhood. Aust Paediatr J 10:273-276. Medline

Isaacs JD, Bodini B, Ciccarelli O, Scadding GK, Thompson AJ (2011) Atopic myelitis in a European woman residing in Japan. J Neurol Neurosurg Psychiatry 82:1022-1024. CrossRef Medline

Isobe N, Kira J, Kawamura N, Ishizu T, Arimura K, Kawano Y (2009) Neural damage associated with atopic diathesis: a nationwide survey in Japan. Neurology 73:790-797. CrossRef Medline

Isobe N, Kanamori Y, Yonekawa T, Matsushita T, Shigeto H, Kawamura N, Kira J (2012) First diagnostic criteria for atopic myelitis with special reference to discrimination from myelitis-onset multiple sclerosis. J Neurol Sci 316:30-35. CrossRef Medline

Jablonski KA, Amici SA, Webb LM, Ruiz-Rosado Jde D, Popovich PG, Partida-Sanchez S, Guerau-de-Arellano M (2015) Novel markers to delineate murine M1 and M2 macrophages. PLoS One 10:e145342. CrossRef Medline

Kanamori Y, Isobe N, Yonekawa T, Matsushita T, Shigeto H, Kawamura N, Yamasaki R, Murai H, Tobimatsu S, Kira J (2013) Multimodality evoked potentials for discrimination of atopic myelitis and multiple sclerosis. Clin Exp Neuroimmunol 4:29-35. CrossRef

Kido-Nakahara M, Buddenkotte J, Kempkes C, Ikoma A, Cevikbas F, Akiyama T, Nunes F, Seeliger S, Hasdemir B, Mess C, Buhl T, Sulk M, Müller FU, Metze D, Bunnett NW, Bhargava A, Carstens E, Furue M, Steinhoff M (2014) Neural peptidase endothelin-converting enzyme 1 regulates endothelin 1-induced pruritus. J Clin Invest 124:2683-2695. CrossRef Medline

Kikuchi H, Osoegawa M, Ochi H, Murai H, Horiuchi I, Takahashi H, Yamabe K, Iwaki T, Mizutani T, Oda M, Kira J (2001) Spinal cord lesions of 
myelitis with hyperIgEemia and mite antigen specific $\operatorname{IgE}$ (atopic myelitis) manifest eosinophilic inflammation. J Neurol Sci 183:73-78. CrossRef Medline

Kira J, Yamasaki K, Kawano Y, Kobayashi T (1997) Acute myelitis associated with hyperIgEemia and atopic dermatitis. J Neurol Sci 148:199-203. CrossRef Medline

Kira J, Kawano Y, Yamasaki K, Tobimatsu S (1998) Acute myelitis with hyperIgEaemia and mite antigen specific IgE: atopic myelitis. J Neurol Neurosurg Psychiatry 64:676-679. CrossRef Medline

Kira J, Isobe N, Kawano Y, Osoegawa M, Ohyagi Y, Mihara F, Murai H (2008) Atopic myelitis with focal amyotrophy: a possible link to Hopkins syndrome. J Neurol Sci 269:143-151. CrossRef Medline

Kobayashi H, Kikuchi K, Tsubono Y, Tagami H (2003) Measurement of electrical current perception threshold of sensory nerves for pruritus in atopic dermatitis patients and normal individuals with various degrees of mild damage to the stratum corneum. Dermatology 206:204-211. CrossRef Medline

Laurence JA, Fatemi SH (2005) Glial fibrillary acidic protein is elevated in superior frontal, parietal and cerebellar cortices of autistic subjects. Cerebellum 4:206-210. CrossRef Medline

Leung JW, Chung SS, Chung SK (2009) Endothelial endothelin-1 overexpression using receptor tyrosine kinase tie-1 promoter leads to more severe vascular permeability and blood brain barrier breakdown after transient middle cerebral artery occlusion. Brain Res 1266:121-129. CrossRef Medline

Liedholm LJ, Eeg-Olofsson O, Ekenberg BE, Nicolaysen RB, Torbergsen T (1994) Acute postasthmatic amyotrophy (Hopkins' syndrome). Muscle Nerve 17:769-772. CrossRef Medline

Lo AC, Chen AY, Hung VK, Yaw LP, Fung MK, Ho MC, Tsang MC, Chung SS, Chung SK (2005) Endothelin-1 overexpression leads to further water accumulation and brain edema after middle cerebral artery occlusion via aquaporin 4 expression in astrocytic end-feet. J Cereb Blood Flow Metab 25:998-1011. CrossRef Medline

Masaki K, Suzuki SO, Matsushita T, Matsuoka T, Imamura S, Yamasaki R, Suzuki M, Suenaga T, Iwaki T, Kira J (2013) Connexin 43 astrocytopathy linked to rapidly progressive multiple sclerosis and neuromyelitis optica. PLoS One 8:e72919. CrossRef Medline

Masuda T, Tsuda M, Yoshinaga R, Tozaki-Saitoh H, Ozato K, Tamura T, Inoue K (2012) IRF8 is a critical transcription factor for transforming microglia into a reactive phenotype. Cell Rep 1:334-340. CrossRef Medline

Matsuo Y, Mihara S, Ninomiya M, Fujimoto M (2001) Protective effect of endothelin type A receptor antagonist on brain edema and injury after transient middle cerebral artery occlusion in rats. Stroke 32:2143-2148. CrossRef Medline

Morgan JT, Chana G, Pardo CA, Achim C, Semendeferi K, Buckwalter J, Courchesne E, Everall IP (2010) Microglial activation and increased microglial density observed in the dorsolateral prefrontal cortex in autism. Biol Psychiatry 68:368-376. CrossRef Medline

Murai H, Arahata H, Osoegawa M, Ochi H, Minohara M, Taniwaki T, Tobimatsu S, Mihara F, Tsuruta Y, Inaba S, Kira J (2004) Effect of immunotherapy in myelitis with atopic diathesis. J Neurol Sci 227:39-47. CrossRef Medline

Nials AT, Uddin S (2008) Mouse models of allergic asthma: acute and chronic allergen challenge. Dis Model Mech 1:213-220. CrossRef Medline

Ochi H, Osoegawa M, Murai H, Minohara M, Taniwaki T, Kira J (2004) Presence of IgE antibodies to bacterial superantigens and increased IL-13producing $\mathrm{T}$ cells in myelitic patients with atopic diathesis. Int Arch Allergy Immunol 134:41-48. CrossRef Medline

Osoegawa M, Ochi H, Minohara M, Murai H, Umehara F, Furuya H, Yamada T, Kira J (2003a) Myelitis with atopic diathesis: a nationwide survey of 79 cases in Japan. J Neurol Sci 209:5-11. CrossRef Medline

Osoegawa M, Ochi H, Kikuchi H, Shirabe S, Nagashima T, Tsumoto T, Tamura Y, Yamabe K, Takahashi H, Iwaki T, Kira J (2003b) Eosinophilic myelitis associated with atopic diathesis: a combined neuroimaging and histopathological study. Acta Neuropathol 105:289-295. CrossRef Medline

Pawankar R, Canonica GW, Holgate ST, Lockey RF (2012) Allergic diseases and asthma: a major global health concern. Curr Opin Allergy Clin Immunol 12:39-41. CrossRef Medline
Pégorier S, Arouche N, Dombret MC, Aubier M, Pretolani M (2007) Augmented epithelial endothelin-1 expression in refractory asthma. J Allergy Clin Immunol 120:1301-1307. CrossRef Medline

Piovezan AP, D’Orléans-Juste P, Frighetto M, Souza GE, Henriques MG, Rae GA (2004) Endothelins contribute towards nociception induced by antigen in ovalbumin-sensitised mice. Br J Pharmacol 141:755-763. CrossRef Medline

Pomonis JD, Rogers SD, Peters CM, Ghilardi JR, Mantyh PW (2001) Expression and localization of endothelin receptors: implications for the involvement of peripheral glia in nociception. J Neurosci 21:999-1006. Medline

Roth N, Beyreiss J, Schlenzka K, Beyer H (1991) Coincidence of attention deficit disorder and atopic disorders in children: empirical findings and hypothetical background. J Abnorm Child Psychol 19:1-13. CrossRef Medline

Rubin SA, Levin ER (1994) Clinical review 53. The endocrinology of vasoactive peptides: synthesis to function. J Clin Endocrinol Metab 78:6-10. CrossRef Medline

Sato S, Isobe N, Yoshimura S, Kanamori Y, Masaki K, Matsushita T, Kira J (2012) HLA-DPB ${ }^{\star} 0201$ is associated with susceptibility to atopic myelitis in Japanese. J Neuroimmunol 251:110-113. CrossRef Medline

Shiratori-Hayashi M, Koga K, Tozaki-Saitoh H, Kohro Y, Toyonaga H, Yamaguchi C, Hasegawa A, Nakahara T, Hachisuka J, Akira S, Okano H, Furue M, Inoue K, Tsuda M (2015) STAT3-dependent reactive astrogliosis in the spinal dorsal horn underlies chronic itch. Nat Med 21:927931. CrossRef Medline

Smith TP, Haymond T, Smith SN, Sweitzer SM (2014) Evidence for the endothelin system as an emerging therapeutic target for the treatment of chronic pain. J Pain Res 7:531-545. CrossRef Medline

Spergel JM, Mizoguchi E, Brewer JP, Martin TR, Bhan AK, Geha RS (1998) Epicutaneous sensitization with protein antigen induces localized allergic dermatitis and hyperresponsiveness to methacholine after single exposure to aerosolized antigen in mice. J Clin Invest 101:1614-1622. CrossRef Medline

Tanaka M, Matsushita T, Tateishi T, Ochi H, Kawano Y, Mei FJ, Minohara M, Murai H, Kira JI (2008) Distinct CSF cytokine/chemokine profiles in atopic myelitis and other causes of myelitis. Neurology 71:974-981. CrossRef Medline

Tsuda M, Shigemoto-Mogami Y, Koizumi S, Mizokoshi A, Kohsaka S, Salter MW, Inoue K (2003) P2X4 receptors induced in spinal microglia gate tactile allodynia after nerve injury. Nature 424:778-783. CrossRef Medline

Tsybikov NN, Petrisheva IV, Kuznik BI, Magen E (2015) Plasma endothelin-1 levels during exacerbation of atopic dermatitis. Allergy Asthma Proc 36:320-324. CrossRef Medline

Waisman A, Hauptmann J, Regen T (2015) The role of IL-17 in CNS diseases. Acta Neuropathol 129:625-637. CrossRef Medline

Xu P, Rosen KM, Hedstrom K, Rey O, Guha S, Hart C, Corfas G (2013) Nerve injury induces glial cell line-derived neurotrophic factor (GDNF) expression in Schwann cells through purinergic signaling and the PKCPKD pathway. Glia 61:1029-1040. CrossRef Medline

Yamasaki R, Lu H, Butovsky O, Ohno N, Rietsch AM, Cialic R, Wu PM, Doykan CE, Lin J, Cotleur AC, Kidd G, Zorlu MM, Sun N, Hu W, Liu L, Lee JC, Taylor SE, Uehlein L, Dixon D, Gu J, et al. (2014) Differential roles of microglia and monocytes in the inflamed central nervous system. J Exp Med 211:1533-1549. CrossRef Medline

Yamasaki R, Zhang J, Koshiishi I, Sastradipura Suniarti DF, Wu Z, Peters C, Schwake M, Uchiyama Y, Kira J, Saftig P, Utsumi H, Nakanishi H (2007) Involvement of lysosomal storage-induced p38 MAP kinase activation in the overproduction of nitric oxide by microglia in cathepsin D-deficient mice. Mol Cell Neurosci 35:573-584. CrossRef Medline

Yoon JH, Joo IS, Li WY, Sohn SY (2009) Clinical and laboratory characteristics of atopic myelitis: Korean experience. J Neurol Sci 285:154-158. CrossRef Medline

Zietkowski Z, Skiepko R, Tomasiak-Lozowska MM, Bodzenta-Lukaszyk A (2010) Anti-IgE therapy with omalizumab decreases endothelin-1 in exhaled breath condensate of patients with severe persistent allergic asthma. Respiration 80:534-542. CrossRef Medline

Zoli A, Mariano M, Fusari A, Bonifazi F, Antonicelli L (2005) Atopic myelitis: first case report outside Japan? Allergy 60:410-411. CrossRef Medline 